\title{
Psychological interventions for people with Parkinson's disease in the early 2020s: Where do we stand?
}

Nicolò Zarottia ${ }^{\mathrm{a}}$, Fiona Eccles ${ }^{\mathrm{a}}$, Jennifer A. Foley ${ }^{\mathrm{b}}$, Andrew Paget ${ }^{\mathrm{b}}$, Sarah

Gunn $^{\mathrm{c}}$, Iracema Leroi ${ }^{\mathrm{e}}$, Jane Simpson ${ }^{\mathrm{a}^{*}}$

${ }^{a}$ Division of Health Research, Faculty of Health and Medicine, Lancaster University, Lancaster, UK

${ }^{b}$ Department of Neuropsychology, National Hospital of Neurology \& Neurosurgery, London, UK; UCL Queen Square Insitute of Neurology, Queen Square, London, WC1N $3 B G$

${ }^{c}$ Department of Neuroscience, Psychology and Behaviour, University of Leicester, Leicester, UK. ORCiD: 0000-0002-8492-060X

${ }^{e}$ Global Brain Health Institute, Trinity College Dublin, Dublin, Ireland. ORCiD: 00000003-1822-3643

*Corresponding author. Tel.: +44 01524 592858. E-mail: j.simpson2@lancaster.ac.uk. Address: Division of Health Research, Faculty of Health and Medicine, Lancaster University, LA1 4YG, Lancaster, UK

\section{Funding}

The present study was funded by the British Psychological Society as part of 'Minds \& Movement', a project aimed at producing UK-based national guidance on psychological approaches to the understanding and treatment of psychological difficulties in adults with motor neurodegenerative conditions. 


\begin{abstract}
Purpose: To explore the heterogeneity of the literature on psychological interventions for psychological difficulties in people with Parkinson's disease (PD).
\end{abstract}

Methods: A scoping review was performed across five major databases (MEDLINE Complete, PsycINFO, CINAHL, Academic Search Ultimate, and Cochrane Library) up to June 2020.

Results: From an initial return of 4911 citations, 56 studies were included, of which 21 were RCTs. A relatively wide range of therapeutic models have been adopted with people with PD, from common therapies such as cognitive behavioural therapy (CBT) and mindfulness, to less frequent approaches, e.g., acceptance and commitment therapy (ACT) and psychodrama. The clinical implications of the findings are discussed, and suggestions are provided for future research on intervention studies and key psychological outcomes.

Conclusions: CBT appears to be effective in treating depression and sleep disorders in people with $\mathrm{PD}$, while psychoeducation programmes alone should be avoided. The use of CBT to improve anxiety, quality of life, and impulse control, as well mindfulnessbased interventions, should be undertaken with some caution because of insufficient research and inconsistent results. As we enter the new decade, more high-quality evidence is required for psychological interventions in people with PD in general, and to corroborate preliminary positive findings on the adoption of less frequent approaches such as ACT.

Keywords: Parkinson's disease; psychotherapy; clinical psychology; psychological interventions; psychological therapy; CBT; mindfulness, ACT. 


\section{Introduction}

Parkinson's disease (PD) is a progressive neurodegenerative condition caused by the death of dopaminergic neurons in the substantia nigra pars compacta of the basal ganglia. This leads to disorders of movement which include bradykinesia, muscular rigidity, rest tremor, and postural and gait impairment (Kalia \& Lang, 2015). Other difficulties involve affect, sleep, pain, gastrointestinal and autonomic symptoms (Chaudhuri \& Schapira, 2006; Weintraub \& Burn, 2011), as well as cognitive deterioration which may ultimately lead to dementia (Emre, 2007; McKeith \& Burn, 2000). Motor symptoms usually appear after the age of 50, although younger onset is also possible (Willis, Schootman, Kung, \& Racette, 2013). PD is the second most common neurodegenerative disease in older people (after Alzheimer's disease), affecting around 1 in 500 individuals in the UK (Mark, 2006). Its worldwide prevalence ranges from 1 to 418 per 100,000 (Zhang \& Roman, 1993) and, due to the ageing population, is expected to increase by $50 \%$ by 2030 (Dorsey et al., 2007). There is no definitive diagnostic test for PD and diagnosis is usually made following the emergence of motor symptoms (Gelb, Oliver, \& Gilman, 1999).

\section{Psychological difficulties in people with PD}

$\mathrm{PD}$ is most commonly conceived as a motor disorder and psychological problems are often under-recognised by healthcare professionals (Barbosa, 2013). In fact, people with PD can experience a wide range of psychological difficulties, including anxiety, depression, apathy, impulse control disorders, and more rarely psychosis (ffytche et al., 2017; Simpson, McMillan, \& Reeve, 2013).

Anxiety is especially common in PD, affecting up to $55 \%$ of people with the condition (Yamanishi et al., 2013). It is often diagnosed as generalised anxiety disorder (GAD), followed closely by social phobia and non-specific clinically relevant anxiety. 
Diagnoses of panic disorder, obsessive compulsive disorder (OCD), and agoraphobia tend to be more rare (Broen, Narayen, Kuijf, Dissanayaka, \& Leentjens, 2016). Similarly, the prevalence of depression in people with PD is estimated to be as high as 56\% (Yamanishi et al., 2013), with a diagnosis of minor depression being the most frequent, followed by major depressive disorder and dysthymia (Reijnders, Ehrt, Weber, Aarsland, \& Leentjens, 2008). In addition, around $40 \%$ of individuals might hold concurrently diagnoses of anxiety and depression (Yamanishi et al., 2013).

All psychological difficulties in PD may occur at any time throughout the course of the disease - sometimes preceding formal diagnosis by many years (Goldman \& Postuma, 2014) - and can be as disabling as motor symptoms (Goldman \& Holden, 2014), with their severity representing a key predictor of health-related quality of life in affected individuals (Leroi et al., 2011). However, our understanding of the psychological impact of PD has been historically dominated by neurobiological conceptualisations (Brown \& Jahanshahi, 1995). These assume that psychological difficulties largely occur as a result of pathophysiological processes, such as changes in dopaminergic systems (Chaudhuri \& Schapira, 2009). Only more recently has it been recognised that psychological issues in PD are likely caused by a mixture of neurobiological, psychological, and indeed social factors, depending on the individual's specific presentation (Simpson, Lekwuwa, \& Crawford, 2013). As a result, more psychologically-informed interventions for people with PD have recently been developed and implemented, with a number of reviews reporting mixed results for cognitive behavioural therapy (CBT) and approaches focused on mindfulness, in particular for anxiety and depression (Armento et al., 2012; Berardelli et al., 2015; Ghielen et al., 2019; Xie et al., 2015; Zečević, 2020). 
However, the vast majority of reviews and meta-analyses on this topic selectively focus on specific therapies with the aim of examining their effectiveness, with most failing to encompass the heterogeneity of models and approaches. In fact, only one recent umbrella review has endeavoured to shed light on the variety of psychological interventions for PD (Kampling, Brendel, \& Mittag, 2019). The results confirmed the heterogenous evidence for CBT's effectiveness and reported novel insight into less investigated approaches (e.g., psychodrama), but failed to identify any of the existing studies which explored mindfulness-based therapies. Moreover, the search strategy showed a strong focus on cognitive interventions and was significantly limited in scope over time, only including publications between 2000 and 2018.

As we have recently passed the second centenary of PD's first description (Parkinson, 1817) and have now entered the 2020s, our current understanding of the applications of various psychological interventions in this population appears very limited. Consequently, the overarching aim of the present review was to provide a comprehensive account of the heterogeneity and effectiveness of approaches to psychological interventions adopted to date with individuals affected by Parkinson's.

\section{Methods}

\section{Identifying the research question}

The present addressed the following research question: which psychological interventions have been explored so far with PD, and what is their effectiveness? To answer this, a scoping review was performed, in accordance with the latest guidelines from The Joanna Briggs Institute (Peters et al., 2020). This approach was adopted in order to explore methodologically heterogenous topics (i.e., both quantitative and qualitative) with a systematic and replicable search strategy without the need for narrow 
research questions, as in traditional systematic reviews (Arksey \& O’Malley, 2005).

\section{Identifying relevant studies}

To be included in the present review, studies had to: a) be related to people with PD; b) involve individuals aged 18 or above; and c) describe the delivery of any psychological intervention targeting psychological outcomes in PD. Qualitative studies were included if consisting of evaluations of psychological interventions.

Studies not related to the concept under investigation, not published in full in the English language, enrolling individuals aged 17 or under, not providing sufficient details on the adopted intervention (e.g., methodological approach), or involving mainly animal models were excluded. Systematic reviews, reviews, commentaries, editorials, conference proceedings, and letters were also excluded. As the overarching aim of this study was to investigate psychological interventions for psychological difficulties in people with PD specifically, interventions targeting physical symptoms or aimed only at family members and/or carers, as well as studies focusing only on cognition and/or neuroimaging were not included.

\section{Study selection}

A comprehensive search was carried out across five major databases (Academic Search Ultimate, CINAHL, Cochrane Library, PsycINFO, PubMed) up until June $1^{\text {st }} 2020$, using a combination of free text terms. Reference lists of included citations and key reviews were also hand-searched to identify any further relevant studies. The logic grid for the search strategy is illustrated in Table 1, while Table 2 provides details on the terms adopted in the searches.

As current guidelines on scoping reviews do not consider a formal quality assessment appropriate for this methodology (Peters et al., 2020), this was not carried 
out for the present review. Nevertheless, efforts were made when possible to highlight any methodological and clinical limitations in the included citations, as well as which studies adopted more robust methodologies such as randomised control trials (RCTs).

\section{Charting the data}

First, the raw results from the searches were filtered for duplicate citations and studies not fully in English. Following this, all titles and abstracts were screened by one reviewer (NZ) against the abovementioned inclusion criteria. In a second phase, all remaining fulltext articles were screened for eligibility by three reviewers (NZ, FE, JF) and confirmed by two more (IL, JS). Although rare, any disagreements between reviewers around the inclusion of studies were solved with collective discussions involving all the authors. The PRISMA flow diagram for the study selection is illustrated in Figure 1.

\section{Collating, summarising, and reporting the results}

Data were extracted independently by three reviewers (NZ, IL, AP) and double-checked for accuracy by a further two (FE, JS).

\section{Consultation}

Since the present study was part of a larger project aimed at drawing the first UK national guidance on psychological approaches to people with neurodegenerative diseases ([name]), a number of stakeholders including key academics and third sector organisations were consulted to review the research question and methodology.

\section{Results}

The database searches identified a total of 4911 citations, reduced to 2094 following the initial filtering for duplicates and language. From these, the screening of titles and 
abstracts led to the exclusion of 2006 studies, leaving 88 full-text articles to consider. A total of 56 studies were eventually included, whose key characteristics and results are showed in Table 3. The findings of the included studies are reported below, categorised by therapeutic approach.

\section{Cognitive Behavioural Therapy (CBT)}

CBT holds that emotional distress and behavioural difficulties arise from "maladaptive" or unhelpful cognitions, which comprise general beliefs about the world, the self, and the future (Hofmann, Asnaani, Vonk, Sawyer, \& Fang, 2012). The therapy is predicated on the assumption that changing these cognitions through therapeutic interventions will reduce distress and problematic behaviours. A total of 36 studies have been carried out to evaluate interventions based on CBT for psychological difficulties in PD, of which only around a third (i.e., 11) were RCTs. The main psychological outcomes addressed were anxiety, depression, quality of life, sleep disorders, and impulse control disorders. While some studies addressed multiple outcomes with their intervention, for the sake of clarity the results are presented separately for each outcome.

\section{Anxiety}

The results from experimental studies targeting anxiety appear to be mixed. Two RCTs with small sample sizes (Calleo et al., 2015; Wuthrich \& Rapee, 2019) both administered CBT individually either in person or via telephone, and found no significant improvements in anxiety when compared to waitlist controls or enhanced care. Another similarly sized RCT (Troeung, Egan, \& Gasson, 2014) compared group CBT to waitlist controls, and found significant and large improvement effects for anxiety at postintervention, as well as at 1-month and 6-month follow-ups. A slightly larger RCT adopting telephone-based CBT tailored for depression also reported significant 
improvements in anxiety (Dobkin et al., 2020). Similar findings were obtained by two quasi-experiments, which found a significant positive effect for the CBT group postintervention when compared to psychoeducation (Berardelli et al., 2018) or no treatment (Dreisig, Beckmann, Wermuth, Skovlund, \& Bech, 1999). However, mixed results were observed in an RCT comparing a CBT-based self-help guided reading resource to provision of simple information about worry (Lawson, Millar, Brown, \& Burn, 2013), finding initial significant reductions for the primary outcome of worry for the intervention group, but no differences in final outcomes at the end of the three months of treatment. In addition, another RCT comparing internet-based CBT with treatment as usual (TAU) reported significant differences for anxiety between the intervention group and controls, but also observed how this was not accompanied by significant improvements in the intervention within-group analysis, suggesting that the effect could be at least partly explained by deterioration in the control group.

On the other hand, the observational studies adopting CBT as the primary intervention for anxiety have reported mostly positive findings. Group CBT for 12 weeks was found to lead to significant improvements in anxiety post-intervention in an uncontrolled pretest-posttest design (Berardelli et al., 2015), and a similar study also found that improvements were maintained at three and six months (Dissanayaka et al., 2017). This was consistent with the findings from a number of case studies (Macht, Pasqualini, \& Taba, 2007; Mohlman et al., 2010; Richardson \& Marshall, 2012; Veazey, Cook, Stanley, Lai, \& Kunik, 2009) except for one (Feeney, Egan, \& Gasson, 2005), which did not observe any significant improvements for anxiety. Similar positive findings were also reported by two studies adopting a multiple baseline single-subject experimental design (SSED; Lebrun, Gély-Nargeot, Rossignol, Geny, \& Bayard, 2019; Reynolds, Saint-Hilaire, Thomas, Barlow, \& Cronin-Golomb, 2019), which found 
significant reductions in anxiety at post-treatment maintained at 6-week and 3-month follow-up.

\section{Depression}

The current evidence from experimental studies suggests that CBT is superior to TAU for improving low mood in PD, either when delivered individually (Dobkin, Menza, Allen, Gara, et al., 2011; Wuthrich \& Rapee, 2019) or in a group (Troeung et al., 2014), as well as over the phone (Dobkin et al., 2020) and the internet (Kraepelien et al., 2020). Most of these studies enrolled participants who met clinical criteria for depression at baseline using validated scales, and those which reported effect sizes described at least mediumsized effects (Dobkin, Menza, Allen, Gara, et al., 2011; Wuthrich \& Rapee, 2019). Two other small RCTs found CBT to be superior to psychoeducation and/or monitoring, either at post-treatment (Veazey et al., 2009), or at 1-month follow-up (Calleo et al., 2015). However, these were both limited by small participant numbers and relatively high attrition rates. Positive results for depression were also observed by two quasiexperiments comparing CBT against psychoeducation (Berardelli et al., 2018) and no treatment (Tiihonen, Lankinen, \& Viemerö, 2012), as well as two multiple baseline SSEDs adopting CBT for insomnia (Lebrun et al., 2019; Reynolds et al., 2019). One of the quasi-experiments also reported significant improvements in apathy (Berardelli et al., 2018).

A number of observational studies have reported CBT to be useful for improving low mood in PD. These included uncontrolled pretest-posttest designs (Berardelli et al., 2015; Dobkin, 2014; Dobkin, Allen, \& Menza, 2007; Dobkin, Interian, Durland, Gara, \& Menza, 2018; Dobkin, Menza, Allen, Tiu, et al., 2011; Shinmei et al., 2016), case series (Cole \& Vaughan, 2005; Dobkin, Allen, \& Menza, 2006; Feeney et al., 2005), and a single case study (Richardson \& Marshall, 2012). Some of the improvements in mood were also 
maintained at 1-month (Dobkin et al., 2006; Feeney et al., 2005) and 3-month (Shinmei et al., 2016) follow-ups.

\section{Quality of life}

The current evidence on the effectiveness of CBT to improve quality of life in PD is characterised by contrasting results, for both experimental and observational studies. Positive findings were reported by experimental designs which compared CBT to a health enhancement programme (Hadinia et al., 2016) and no treatment (Tiihonen et al., 2012). Similar positive effects were reported when adopting internet-based CBT (Kraepelien et al., 2020), while the use of telephone-based CBT yielded positive results in one RCT (Dobkin et al., 2020), but not in another (Wuthrich \& Rapee, 2019).

Findings from observational studies showed significant improvements in quality of life post-intervention after group CBT (Berardelli et al., 2015) or brief CBT (Osawa, Kamei, Nozaki, Furusawa, \& Murata, 2020), but no notable differences at all time points after mixed in-person and telephone-delivered individual CBT in another (Veazey et al., 2009).

\section{Sleep disorders}

To date, CBT has shown very promising results for treating sleep disorders in PD. In particular, four RCTs showed significant improvements in participants' levels of insomnia and sleep quality when comparing face-to-face or computerised CBT with education on basic sleep hygiene (Leroi, Baker, Kehoe, Daniel, \& Byrne, 2010; Patel et al., 2017), sham light therapy (Rios Romenets et al., 2013), or TAU (Kraepelien et al., 2020). Similarly, positive findings were observed in a multiple baseline SSED (Reynolds et al., 2019), an uncontrolled pretest-posttest design (Yang \& Petrini, 2012), and two case series (Humbert, Findley, Hernandez-Con, \& Chahine, 2017; Osawa et al., 2020), with 
benefits being maintained at 3-month follow-up in some cases (Reynolds et al., 2019; Yang \& Petrini, 2012).

\section{Impulse control disorders (ICDs)}

The extant evidence on the efficacy of CBT for impulse control disorders (ICDs) in PD is characterised by just two studies, showing mixed results. The larger investigation consists of an RCT which randomised 45 people with PD with ICDs to either an intervention involving 12 sessions of face-to-face CBT or a waitlist (Okai et al., 2013). At the 6-month outcome point, $44 \%$ of participants in the CBT group no longer met clinical criteria for an ICD, compared to $29 \%$ of waitlist controls.

A second study (Jiménez-Murcia et al., 2012) adopted a quasi-experimental design to compare people with PD experiencing pathological gambling to controls with pathological gambling alone on 16 weekly sessions of CBT. The results revealed no difference between groups following the intervention. However, higher dropout and relapse rates were observed among the PD participants compared to those without PD.

\section{Mindfulness}

Mindfulness-based approaches focus on bringing the attention to the present moment and accepting feelings, sensations, and emotions non-judgementally, including the experience of illness (Kabat-Zinn, 2006). When adapted for neurological conditions, such approaches may emphasise acceptance of discomfort and physical changes, focusing on appreciation of the abilities and resources which remain, and may include elements of cognitive therapy (mindfulness-based cognitive therapy; MBCT) or focus on stress reduction (mindfulness-based stress reduction; MBSR).

A total of 10 intervention studies have adopted approaches based on mindfulness to target psychological difficulties in PD. Of these, five were RCTs (Advocat et al., 2016; 
Kwok et al., 2019; Pickut et al., 2015; Rodgers et al., 2019; Son \& Choi, 2018). The most commonly addressed psychological outcomes were anxiety, depression, and quality of life. As with CBT, while some interventions addressed more than one outcome, the results are presented separately for clarity.

\section{Anxiety}

The use of mindfulness-based interventions to address anxiety in PD has been evaluated by three RCTs (Kwok et al., 2019; Rodgers et al., 2019; Son \& Choi, 2018) and two uncontrolled pretest-posttest studies (Birtwell et al., 2017; Dissanayaka et al., 2016). Most reported an improvement in anxiety post-intervention, with some effects maintained at 2-month (Birtwell et al., 2017) and 6-month follow-ups (Dissanayaka et al., 2016). However, one of the RCTs (Rodgers et al., 2019) did not find any significant improvements compared to waitlist controls. Moreover, there was some variation in terms of intervention delivery and content, with two studies using the same protocol based on six two-hour sessions of MBCT (Dissanayaka et al., 2016; Rodgers et al., 2019), two adopting an MBSR course (Birtwell et al., 2017; Son \& Choi, 2018), and one an adapted yoga intervention that included components of mindfulness across eight 90-minute sessions (Kwok et al., 2019). A number of adaptations were made to account for the PD population, including omitting certain exercises involving motor or sensory components, shortening sessions and meditation practices, simplifying language, and using more relevant metaphors.

\section{Depression}

The current evidence on using mindfulness techniques to improve depression in PD consists of four RCTs (Kwok et al., 2019; Pickut et al., 2015; Rodgers et al., 2019; Son \& Choi, 2018) and three uncontrolled pretest-posttest studies (Birtwell et al., 2017; Cash 
et al., 2015; Dissanayaka et al., 2016), and shows mixed results. In particular, studies using MBCT or MBSR have reported significant improvements in depression (Cash et al., 2015; Rodgers et al., 2019), with large effect sizes. These findings are consistent with those from a qualitative investigation, which reported that people with PD who participated in a 8-week MCBT course found MCBT to be an acceptable and helpful form of group intervention (Fitzpatrick, Simpson, \& Smith, 2010). Significant improvements were also observed following the adoption of mindfulness-based yoga, which were maintained at 3-month follow-up (Kwok et al., 2019). However, it should be noted that, unlike the CBT interventions, two of these studies excluded people with PD with major depression (Cash et al., 2015; Kwok et al., 2019), while one (Rodgers et al., 2019) used no depression inclusion criteria and found that the group average depression score was in the normal range. In addition, three other studies which adopted a form of MBSR found contrasting results, with one reporting significant improvements both post-intervention and at follow-up (Birtwell et al., 2017), one only reporting improvements at postintervention (Dissanayaka et al., 2016), and one reporting no effect on depression at all (Pickut et al., 2015).

\section{Quality of life}

Similarly to depression, the current findings on the impact of mindfulness-based interventions on quality of life in PD appear to be mixed. Among the RCTs, only one (Son \& Choi, 2018) showed significant improvements in quality of life compared to waitlist when adopting an MBSR exercise programme, while the other two found no positive effect for an 8-week mindfulness-based intervention (Pickut et al., 2015) or a group mindfulness-based lifestyle programme (Advocat et al., 2016). However, a qualitative evaluation of the latter found that, following the intervention, many participants felt increased levels of perceived control and acceptance of disease 
progression, as well as improved social relationships and self-confidence (Vandenberg et al., 2018).

Considering the observational evidence, one uncontrolled pretest-posttest design found no significant effect on quality of life for an 8-week group MBSR course (Birtwell et al., 2017), while another reported significant improvements for a manualised group mindfulness intervention tailored for PD at post-intervention, but not at 6-month followup (Dissanayaka et al., 2016).

\section{Psychoeducation}

Psychoeducation focuses on developing individuals' understanding about illness and themselves in relation to their condition by providing of information and using exercises (Walsh, 2010). The aim is to empower the individual to manage their condition and their own reactions to it more successfully, and consequently improve their well-being. A total of four studies have so far examined the use of PD-specific psychoeducation programmes to manage daily aspects of the disease (e.g., diet and movement) and improve low mood, two of which were RCTs (Flores Alves Dos Santos et al., 2017; Guo et al., 2009).

One RCT (Flores Alves Dos Santos et al., 2017) compared a group psychoeducation programme designed for people with PD undergoing subthalamic nucleus deep brain stimulation (STN-DBS) against standard STN-DBS aftercare. The results showed no significant difference in social adjustment between the two groups at 1-year follow-up, although the finding became significant at 2-year. Another RCT (Guo et al., 2009) found that three 1-hour psychoeducation lectures and 24 subsequent 30minute individual sessions did not lead to an objective improvement in low mood when compared to waitlist controls. However, the study did not recruit people with PD who had clinically significant levels of depression, and the intervention group's average depression score was in the normal range, making reductions harder to evidence. 
An uncontrolled pretest-posttest design (Macht et al., 2007) evaluated a patient education programme based on information and self-monitoring sessions across seven European countries (Spain, Finland, Italy, The Netherlands, United Kingdom, Estonia, Germany). The results showed no significant improvements in self-rated depression or quality of life at post-intervention. A recent qualitative study (Soundy et al., 2019) explored the experiences of people with PD who underwent First Steps, a 2-day peer-led psychoeducational intervention for people with a new diagnosis of PD. The results showed that the participants engaged well with the programme, showing improved exercise behaviour and coping mechanisms at post-intervention. Proposed mechanisms of change included improved perceived control, hope and action, changes in personal mind-set, as well as opportunities within the groups for social comparison, social control, and peer-sharing. However, no quantitative evaluation of the efficacy of the programme appears to be currently available.

\section{Behavioural Relaxation Training (BRT)}

BRT focuses on progressive muscle relaxation techniques aimed at relieving muscular tension, on the hypothesis that it represents a physiological response to anxiety, and that therefore relaxing muscles will reduce anxious symptoms (McCallie, Blum, \& Hood, 2006). Techniques may involve progressive attention to muscle groups along with the act of tensing and releasing in turn while focusing on the sensation of release following tension, and this may be supported by relaxing music or guided narratives. Two single case studies reported reductions in both therapist-rated and patient-rated measures for social anxiety (Lundervold, Pahwa, \& Lyons, 2013) and generalised anxiety (Lundervold, Pahwa, \& Lyons, 2008) post-treatment. While both studies employed BRT techniques that taught 10 overt relaxed behaviours, the latter also combined imagery and coping techniques. Sessions were short, lasting around 15 to 20 minutes and required daily 
practice, and both studies reported the intervention as acceptable to participants.

\section{Other approaches}

Along with the most commonly adopted therapeutic models, a number of single studies exploring other less frequent approaches were identified by the present review. These are briefly outlined below, in descending order of study methodological complexity.

\section{Acceptance and Commitment Therapy (ACT)}

ACT aims to improve individuals' acceptance of distressing thoughts, beliefs, sensations and emotions, contending that this will generate behavioural change and consequently improved quality of life (Hayes, 2004). Emphasis is usually put on moving towards key goals and acting upon values which are most important to the person, designing behavioural changes which direct one towards living these values. One RCT explored the adoption of ACT to target self-efficacy and anxiety in people with PD (Ghielen et al., 2017). The intervention consisted of a group body awareness training (BEWARE) based on psycho-education, training in ACT, imaginary exposure using FEEL (Feeling Experiences Enriches Living) exercises, diminishing avoidance behaviour, physical exercises, and homework assignments. The results showed a significant improvement in emotional well-being but no changes in self-efficacy.

\section{Psychodrama}

Psychodrama is a therapeutic technique based on discussions of interactions and the dramatisation and role-playing of situations of daily life from an individual's past (Moreno, 1946). One RCT evaluated a psychodrama intervention for people with PD consisting of two 90-minute group sessions every fortnight (Sproesser, Viana, Quagliato, $\&$ de Souza, 2010). The intervention was compared to a waitlist control group, and the 
results showed significant improvements in anxiety, depression, and quality of life at post-intervention.

\section{Behavioural Activation (BA)}

BA focuses on treating mood difficulties by trying to increase participants' active involvement in therapy and life (Jacobson, Martell, \& Dimidjian, 2001). Common techniques include scheduling activities and self-monitoring. An uncontrolled pretestposttest design (Butterfield et al., 2017) found that six weeks of activity scheduling and monitoring significantly reduced apathy and depression in 27 participants with PD, and these gains were maintained at 1-month follow-up. The targets for the activity scheduling were first agreed at a 2-hour in-person planning session, and then supported by automated reminders and short weekly telephone calls.

\section{Eye Movement Desensitization and Reprocessing (EMDR)}

EMDR focuses on reprocessing of traumatic memories, including images, emotional and physical responses, and changes in self-representation (Shapiro, 2017). The aim is to support the brain to process trauma, helping individuals develop more positive selfrepresentations, improve well-being, and move forwards with their lives. A single case study adopted EMDR to address trauma in a woman with Parkinson's disease dementia (PDD; Ahmed, Mosquera, \& Ross, 2018). While some improvement on subjective reporting of trauma symptoms and resilience were observed at post-intervention and 9month follow-up, no changes were found in anxiety and depression. Moreover, some difficulties in administering EMDR were reported, as eye movements were slowed as a consequence of PD. However, this study is notable for being the only one that included a person with PDD. While most interventions to address mood difficulties have excluded people with PD with any signs of cognitive impairment, this study provided preliminary 
evidence which suggests that psychological therapies may be both required and received well by people with PDD.

\section{Discussion}

\section{Summary of main findings}

The present review aimed at providing a comprehensive account of the breadth and effectiveness of psychological interventions in use for a broadly-defined set of psychological difficulties with people with PD. From an initial return of 4911 citations, 56 studies were eventually considered eligible for inclusion. While these covered some of the most common therapeutic models alongside a few less frequent approaches, only 21 were RCTs. Moreover, only six of these (Advocat et al., 2016; Dobkin et al., 2011; Dobkin et al., 2020; Kraepelien et al., 2020; Kwok et al., 2019; Son \& Choi, 2018) enrolled samples of 30 or more participants.

CBT was by far the most common approach, with 36 papers adopting it in some form. The evidence suggests that CBT can be effective to address depression and sleep disorders in people with PD, not only when compared to TAU, but also against other psychotherapy approaches (e.g., psychoeducation; Berardelli et al., 2018). However, the same cannot be stated for anxiety, quality of life, and impulse control disorders (ICDs), for which the literature presents mixed results and, in the case of ICDs, is also still sparse. These findings appear to be fairly consistent with what has been reported from previous targeted systematic reviews (Armento et al., 2012; Berardelli et al., 2015; Dobkin et al., 2008; Xie et al., 2015; Zečević, 2020). As only 11 out of 36 studies adopting CBT were RCTs (Calleo et al., 2015; Dobkin, Menza, Allen, Gara, et al., 2011; Dobkin et al., 2020; Hadinia et al., 2016; Kraepelien et al., 2020; Lawson et al., 2013; Leroi et al., 2010; Okai et al., 2013; Patel et al., 2017; Troeung et al., 2014; 
Wuthrich \& Rapee, 2019), further high-quality research is required to shed light on the impact of this approach on all these psychological outcomes.

The second most common psychotherapeutic model was mindfulness, with 10 studies adopting one of its many variations (e.g., MBCT, MBSR, mindfulness yoga), five of which were RCTs (Advocat et al., 2016; Kwok et al., 2019; Pickut et al., 2015; Rodgers et al., 2019; Son \& Choi, 2018). However, the current evidence on mindfulness-based approaches for people with PD was also characterised by contrasting results, with no clear indication of their efficacy for anxiety, depression, or quality of life. Where positive results were found, a number of potential mechanisms of change were highlighted, including perceived control and self-confidence (e.g., Vandenberg et al., 2018). Therefore, further more comprehensive studies, possibly involving larger sample sizes, are urgently needed.

Psychoeducation programmes were adopted by four studies, of which two were RCTs (Flores Alves Dos Santos et al., 2017; Guo et al., 2009). The results are mostly negative, with all the quantitative studies finding no significant impact on depression (Guo et al., 2009; Macht et al., 2007), social adjustment (Flores Alves Dos Santos et al., 2017), and quality of life (Macht et al., 2007), and only one qualitative evaluation (Soundy et al., 2019) showing promising results for a peer-led psychoeducational intervention for newly diagnosed people with PD ('First Steps'). However, similarly to mindfulness, the latter highlighted a number of potential mechanisms causing positive change which included perceived control and individual mindset (Soundy et al., 2019), thus reinforcing the case for further exploration of the concept of perceived control within this population.

The current preliminary evidence on the use of BRT - based on two single case studies (Lundervold et al., 2008, 2013) - appears to be positive, with both investigations 
reporting reductions in therapist- and patient-rated measures of anxiety at postintervention. However, this needs to be confirmed by further higher quality experimental investigations.

Finally, tentative results are available from single studies exploring some forms of therapy which are less commonly adopted with people with PD. In particular, promising findings were reported for the use of ACT (Ghielen et al., 2017), psychodrama (Sproesser et al., 2010), and BA (Butterfield et al., 2017), while somewhat mixed results were observed for EMDR (Ahmed et al., 2018). For all of these, further explorations of their feasibility, effectiveness, and acceptability are currently needed.

\section{Clinical implications and future directions}

Even though the importance of psychological approaches in people with PD has received more recognition compared to other neurodegenerative conditions, such as Huntington's disease and motor neuron disease (Anestis, Eccles, Fletcher, French, \& Simpson, 2020; Simpson et al., 2019; Zarotti, Dale, Eccles, \& Simpson, 2020; Zarotti, Mayberry, Ovaska-stafford, Eccles, \& Simpson, 2020), the current literature around psychological interventions for PD is mainly characterised by low-level and/or underpowered studies, and more comprehensive high-powered RCTs are urgently needed. In addition, since only five studies out of 56 involved samples with a mean age lower than 60, all of which showed promising results (Berardelli et al., 2015; Dreisig et al., 1999; Lundervold et al., 2013; Okai et al., 2013; Sproesser et al., 2010), further investigations are required to explore the impact of psychological interventions in younger patients, in particular due to the potentially lower severity of cognitive and motor difficulties.

Based on the current evidence from this review, CBT may be recommended as an effective treatment for depression and sleep disorders in PD, especially with an 
intervention duration ranging between eight and 12 weeks. However, it is currently more equivocal if it is effective for anxiety, quality of life, and ICDs, as well as with briefer forms of CBT in general (e.g., six weeks or less). A similar note of caution is suggested when considering mindfulness-based interventions, due to the lack of clear results on the effectiveness of either MBCT or MBSR. The adoption of psychoeducation programmes alone, on the other hand, cannot be recommended due to predominantly negative findings with this population. In addition, data from single studies appear to suggest that ACT, psychodrama, BA, and BRT may represent effective and feasible approaches for psychological difficulties in people with PD. However, no specific recommendation can be made on the evidence presently available. A number of suggestions for future research may also be offered from the findings of the present review. In particular, besides the need for more comprehensive investigations of the therapeutic models outlined above, a number of relevant psychological outcomes for people with PD are currently neglected. For instance, although the development of ICDs has a clear psychological component (Delaney, Leroi, Simpson, \& Overton, 2012; Delaney, Simpson, \& Leroi, 2012), only two studies have evaluated the effectiveness of a psychological intervention for ICDs (Jiménez-Murcia et al., 2012; Okai et al., 2013). Similarly, despite apathy affecting up to $40 \%$ of people with PD (den Brok et al., 2015), only two studies to date have explored psychological therapies to target it specifically, both finding promising results (Berardelli et al., 2018; Butterfield et al., 2017).

In addition, even though perceived control is currently considered a critical factor for successful psychological adaptation to chronic illness (Dempster, Howell, \& McCorry, 2015; Egede \& Ellis, 2008) - and neurodegenerative conditions in particular (Eccles \& Simpson, 2011; Simpson, Chatzidamianos, \& Eccles, 2015; Zarotti, Coates et 
al., 2019; Zarotti, Simpson, \& Fletcher, 2019) - no intervention study has specifically addressed it as an outcome in people with PD. However, the results from two qualitative evaluations identified in this review have highlighted the potential of perceived control in supporting the implementation of mindfulness-based therapy (Vandenberg et al., 2018) and psychoeducational programmes (Soundy et al., 2019), further strengthening the case for more thorough explorations of this construct in this population, and its impact on acceptability and response to psychological treatment.

Considering that people with PD experience a progressive loss of function, ability, and confidence as their condition develops, a focus on improving resilience also appears important. To date, however, there have been no studies of psychological therapies in PD with the aim of increasing resilience specifically, with only a trial of cognitive stimulation (Leroi et al., 2019) and a single case using EMDR (Ahmed et al., 2018) exploring it as a secondary outcome. Thus, there is a clear need for future research to consider how resilience can be best enhanced in affected individuals.

PD can also be associated with psychotic problems, such as hallucinations across different sensory modalities (Goetz, Stebbins, \& Ouyang, 2011). Although these can fluctuate over the course of the condition, they generally tend to increase over time (ffytche et al., 2017). Research in this area is urgently needed to interpret the importance of psychosocial factors in these experiences (Todd, Simpson, \& Murray, 2010) and psychological approaches for psychosis (Louise, Fitzpatrick, Strauss, Rossell, \& Thomas, 2018) in the context of Parkinson's. As no study has yet been carried out to evaluate any psychological intervention for psychosis in people with PD - and very little is also known regarding how affected individuals cope with these symptoms - future research in this area should represent a priority. 
Finally, the intrinsic limitations of scoping reviews (e.g., lack of quantitative synthesis and formal qualitative assessment of evidence) should be considered when interpreting the abovementioned results. While this methodology was appropriate for the wider aim of the present study, further more focused systematic reviews and metaanalyses are warranted in the future for each therapeutic approach in PD.

\section{Conclusions}

The literature available to date shows that a relatively wide range of approaches to psychological interventions has been adopted with people with Parkinson's. Among these, CBT may be the most effective in treating depression and sleep disorders but its impact on anxiety, quality of life, and impulse control disorders is still unclear. For the

same reason, evidence is still limited regarding the adoption of mindfulness-based interventions, while the efficacy of psychoeducation programmes alone is currently unproven. As we enter the new decade, more high-quality evidence is required to increase our understanding of psychological interventions for people with PD in general, as well as to confirm preliminary positive findings on the adoption of ACT, BA, BRT, and psychodrama.

\section{References}

Advocat, J., Enticott, J., Vandenberg, B., Hassed, C., Hester, J., \& Russell, G. (2016). The effects of a mindfulness-based lifestyle program for adults with Parkinson's disease: a mixed methods, wait list controlled randomised control study. $B M C$ Neurol, 16, 166. https://doi.org/10.1186/s12883-016-0685-1

Ahmed, A., Mosquera, D., \& Ross, C. A. (2018). EMDR Therapy for an Elderly Woman With Depression, Traumatic Memories, and Parkinson's Disease 
Dementia: A Case Study. Journal of EMDR Practice and Research, 12(1), 16-23. https://doi.org/10.1891/1933-3196.12.1.16

Anestis, E., Eccles, F., Fletcher, I., French, M., \& Simpson, J. (2020). Giving and receiving a diagnosis of a progressive neurological condition: A scoping review of doctors' and patients' perspectives. Patient Education and Counseling, (2019). https://doi.org/10.1016/j.pec.2020.03.023

Arksey, H., \& O’Malley, L. (2005). Scoping studies: towards a methodological framework. International Journal of Social Research Methodology, 8(1), 19-32. https://doi.org/10.1080/1364557032000119616

Armento, M. E., Stanley, M. A., Marsh, L., Kunik, M. E., York, M. K., Bush, A. L., \& Calleo, J. S. (2012). Cognitive behavioral therapy for depression and anxiety in Parkinson's disease: a clinical review. J Parkinsons Dis, 2(2), 135-151. https://doi.org/10.3233/JPD-2012-12080

Barbosa, E. R. (2013). Non-motor symptoms in Parkinson's disease. Arquivos de Neuro-Psiquiatria, 71(4), 203-204. https://doi.org/10.1590/0004-282X20130001

Berardelli, I, Bloise, M. C., Bologna, M., Conte, A., Pompili, M., Lamis, D. A., ... Fabbrini, G. (2018). Cognitive behavioral group therapy versus psychoeducational intervention in Parkinson's disease. Neuropsychiatr Dis Treat, 14, 399-405. https://doi.org/10.2147/NDT.S152221

Berardelli, I, Pasquini, M., Roselli, V., Biondi, M., Berardelli, A., \& Fabbrini, G. (2015). Cognitive Behavioral Therapy in Movement Disorders: A Review. Mov Disord Clin Pract, 2(2), 107-115. https://doi.org/10.1002/mdc3.12160 
Berardelli, Isabella, Pasquini, M., Bloise, M., Tarsitani, L., Biondi, M., Berardelli, A., \& Fabbrini, G. (2015). CBT Group Intervention for Depression, Anxiety, and Motor Symptoms in Parkinson's Disease: Preliminary Findings. International Journal of Cognitive Therapy, 8(1), 11-20. https://doi.org/10.1521/ijct.2015.8.1.11

Birtwell, K., Dubrow-Marshall, L., Dubrow-Marshall, R., Duerden, T., \& Dunn, A. (2017). A mixed methods evaluation of a Mindfulness-Based Stress Reduction course for people with Parkinson's disease. Complement Ther Clin Pract, 29, 220228. https://doi.org/10.1016/j.ctcp.2017.10.009

Broen, M. P. G., Narayen, N. E., Kuijf, M. L., Dissanayaka, N. N. W., \& Leentjens, A. F. G. (2016). Prevalence of anxiety in Parkinson's disease: A systematic review and meta-analysis. Movement Disorders, 31(8), 1125-1133. https://doi.org/10.1002/mds.26643

Brown, R., \& Jahanshahi, M. (1995). Depression in Parkinson's disease: a psychosocial viewpoint. Advances in Neurology, 65, 61-84. Retrieved from http://www.ncbi.nlm.nih.gov/pubmed/7872153

Butterfield, L. C., Cimino, C. R., Salazar, R., Sanchez-Ramos, J., Bowers, D., \& Okun, M. S. (2017). The Parkinson's Active Living (PAL) Program. J Geriatr Psychiatry Neurol, 30(1), 11-25. https://doi.org/10.1177/0891988716673467

Calleo, J. S., Amspoker, A. B., Sarwar, A. I., Kunik, M. E., Jankovic, J., Marsh, L., ... Stanley, M. A. (2015). A Pilot Study of a Cognitive-Behavioral Treatment for Anxiety and Depression in Patients With Parkinson Disease. J Geriatr Psychiatry Neurol, 28(3), 210-217. https://doi.org/10.1177/0891988715588831

Cash, T. V., Ekouevi, V. S., Kilbourn, C., \& Lageman, S. K. (2015). Pilot Study of a 
Mindfulness-Based Group Intervention for Individuals with Parkinson’s Disease and Their Caregivers. Mindfulness, 7(2), 361-371. https://doi.org/10.1007/s12671015-0452-1

Chaudhuri, K. Ray, \& Schapira, A. H. (2009). Non-motor symptoms of Parkinson's disease: dopaminergic pathophysiology and treatment. The Lancet Neurology, 8(5), 464-474. https://doi.org/10.1016/S1474-4422(09)70068-7

Chaudhuri, Kallol R, \& Schapira, A. H. V. (2006). Non-motor symptoms of PD diagnosis and management. The Lancet Neurology, 5(March), 235-245. Retrieved from http://neurology.thelancet.com

Cole, K., \& Vaughan, F. L. (2005). Brief Cognitive Behavioural Therapy for Depression Associated with Parkinson's Disease: a Single Case Series. Behav Cogn Psychother, 33(1), 89-102. https://doi.org/10.1017/s1352465804001791

Delaney, M., Leroi, I., Simpson, J., \& Overton, P. G. (2012). Impulse Control Disorders in Parkinson's Disease: A Psychosocial Perspective. Journal of Clinical Psychology in Medical Settings, 19(3), 338-346. https://doi.org/10.1007/s10880012-9302-7

Delaney, M., Simpson, J., \& Leroi, I. (2012). Perceptions of cause and control of impulse control behaviours in people with Parkinson's disease. British Journal of Health Psychology, 17(3), 522-535. https://doi.org/10.1111/j.20448287.2011.02052.x

Dempster, M., Howell, D., \& McCorry, N. K. (2015). Illness perceptions and coping in physical health conditions: A meta-analysis. Journal of Psychosomatic Research, 79(6), 506-513. https://doi.org/10.1016/j.jpsychores.2015.10.006 
den Brok, M. G. H. E., van Dalen, J. W., van Gool, W. A., Moll van Charante, E. P., de Bie, R. M. A., \& Richard, E. (2015). Apathy in Parkinson's disease: A systematic review and meta-analysis. Movement Disorders, 30(6), 759-769. https://doi.org/10.1002/mds.26208

Dissanayaka, N. N., Idu Jion, F., Pachana, N. A., O’Sullivan, J. D., Marsh, R., Byrne, G. J., \& Harnett, P. (2016). Mindfulness for Motor and Nonmotor Dysfunctions in Parkinson's Disease. Parkinsons Dis, 2016, 7109052. https://doi.org/10.1155/2016/7109052

Dissanayaka, N. N. W. W., Pye, D., Mitchell, L. K., Byrne, G. J., O’Sullivan, J. D., Marsh, R., ... Pachana, N. A. (2017). Cognitive Behavior Therapy for Anxiety in Parkinson's Disease: Outcomes for Patients and Caregivers. Clinical Gerontologist, 40(3), 159-171. https://doi.org/10.1080/07317115.2016.1240131

Dobkin, R. D. F., Menza, M., \& Bienfait, K. L. (2008). CBT for the treatment of depression in Parkinson's disease: a promising nonpharmacological approach. Expert Rev Neurother, 8(1), 27-35. https://doi.org/10.1586/14737175.8.1.27

Dobkin, R D. (2014). The relationship between telephone-administered cognitivebehavioral therapy for depression and neuropsychological functioning in Parkinson's disease. J Neuropsychiatry Clin Neurosci, 26(2), E10-1. https://doi.org/10.1176/appi.neuropsych.13030065

Dobkin, R D, Allen, L. A., \& Menza, M. (2007). Cognitive-behavioral therapy for depression in Parkinson's disease: a pilot study. Mov Disord, 22(7), 946-952. https://doi.org/10.1002/mds.21455

Dobkin, R D, Interian, A., Durland, J. L., Gara, M. A., \& Menza, M. A. (2018). 
Personalized Telemedicine for Depression in Parkinson's Disease: A Pilot Trial. $J$ Geriatr Psychiatry Neurol, 31(4), 171-176.

https://doi.org/10.1177/0891988718783274

Dobkin, R D, Menza, M., Allen, L. A., Gara, M. A., Mark, M. H., Tiu, J., ... Friedman, J. (2011). Cognitive-behavioral therapy for depression in Parkinson's disease: a randomized, controlled trial. Am J Psychiatry, 168(10), 1066-1074. https://doi.org/10.1176/appi.ajp.2011.10111669

Dobkin, R D, Menza, M., Allen, L. A., Tiu, J., Friedman, J., Bienfait, K. L., ... Mark, M. H. (2011). Telephone-based cognitive-behavioral therapy for depression in Parkinson disease. J Geriatr Psychiatry Neurol, 24(4), 206-214. https://doi.org/10.1177/0891988711422529

Dobkin, Roseanne D., Mann, S. L., Gara, M. A., Interian, A., Rodriguez, K. M., \& Menza, M. (2020). Telephone-based cognitive behavioral therapy for depression in Parkinson disease: A randomized controlled trial. Neurology, 94(16), E1764E1773. https://doi.org/10.1212/WNL.0000000000009292

Dobkin, Roseanne DeFronzo, Allen, L. A., \& Menza, M. (2006). A cognitivebehavioral treatment package for depression in Parkinson's disease. Psychosomatics, 47(3), 259-263. https://doi.org/10.1176/appi.psy.47.3.259

Dorsey, E. R., Constantinescu, R., Thompson, J. P., Biglan, K. M., Holloway, R. G., Kieburtz, K., ... Tanner, C. M. (2007). Projected number of people with Parkinson disease in the most populous nations, 2005 through 2030. Neurology, 68(5), 384386. https://doi.org/10.1212/01.wnl.0000247740.47667.03

Dreisig, H., Beckmann, J., Wermuth, L., Skovlund, S., \& Bech, P. (1999). Psychologic 
effects of structured cognitive psychotherapy in young patients with Parkinson disease: A pilot study. Nord J Psychiatry, 53(3), 217-221.

https://doi.org/10.1080/080394899427232

Eccles, F. J. R., \& Simpson, J. (2011). A review of the demographic, clinical and psychosocial correlates of perceived control in three chronic motor illnesses. Disability and Rehabilitation, 33(13-14), 1065-1088. https://doi.org/10.3109/09638288.2010.525287

Egede, L. E., \& Ellis, C. (2008). The effects of depression on diabetes knowledge, diabetes self-management, and perceived control in indigent patients with type 2 diabetes. Diabetes Technology and Therapeutics, 10(3), 213-219. https://doi.org/10.1089/dia.2007.0278

Emre, M. (2007). Dementia Associated with Parkinsons Disease. European Neurological Review, (2), 46. https://doi.org/10.17925/enr.2007.00.02.46

Farabaugh, A., Locascio, J. J., Yap, L., Growdon, J., Fava, M., Crawford, C., ... Alpert, J. E. (2010). Cognitive-behavioral therapy for patients with Parkinson's disease and comorbid major depressive disorder. Psychosomatics: Journal of Consultation and Liaison Psychiatry, 51(2), 124-129. https://doi.org/10.1016/s00333182(10)70672-1

Feeney, F., Egan, S., \& Gasson, N. (2005). Treatment of depression and anxiety in Parkinson's Disease: A pilot study using group cognitive behavioural therapy. Clinical Psychologist, 9(1), 31-38. https://doi.org/10.1080/13284200500048240

Ffytche, D. H., Creese, B., Politis, M., Chaudhuri, K. R., Weintraub, D., Ballard, C., \& Aarsland, D. (2017). The psychosis spectrum in Parkinson disease. Nature Reviews 
Neurology, 13(2), 81-95. https://doi.org/10.1038/nrneurol.2016.200

Fitzpatrick, L., Simpson, J., \& Smith, A. (2010). A qualitative analysis of mindfulnessbased cognitive therapy (MBCT) in Parkinson's disease. Psychology and Psychotherapy: Theory, Research and Practice, 83(2), 179-192.

Flores Alves Dos Santos, J., Tezenas du Montcel, S., Gargiulo, M., Behar, C., Montel, S., Hergueta, T., ... Welter, M.-L. (2017). Tackling psychosocial maladjustment in Parkinson's disease patients following subthalamic deep-brain stimulation: A randomised clinical trial. PLoS ONE, 12(4), e0174512. https://doi.org/10.1371/journal.pone.0174512

Gelb, D. J., Oliver, E., \& Gilman, S. (1999). Diagnostic Criteria for Parkinson Disease. Archives of Neurology, 56(1), 33. https://doi.org/10.1001/archneur.56.1.33

Ghielen, I., Rutten, S., Boeschoten, R. E., Houniet-de Gier, M., van Wegen, E. E. H. H., van den Heuvel, O. A., \& Cuijpers, P. (2019). The effects of cognitive behavioral and mindfulness-based therapies on psychological distress in patients with multiple sclerosis, Parkinson's disease and Huntington's disease: Two meta-analyses. Journal of Psychosomatic Research, 122(May), 43-51. https://doi.org/10.1016/j.jpsychores.2019.05.001

Ghielen, I., van Wegen, E. E. H., Rutten, S., de Goede, C. J. T., Houniet-de Gier, M., Collette, E. H., ... van den Heuvel, O. A. (2017). Body awareness training in the treatment of wearing-off related anxiety in patients with Parkinson's disease: Results from a pilot randomized controlled trial. Journal of Psychosomatic Research, 103(May), 1-8. https://doi.org/10.1016/j.jpsychores.2017.09.008

Goetz, C. G., Stebbins, G. T., \& Ouyang, B. (2011). Visual plus nonvisual 
hallucinations in Parkinson's disease: Development and evolution over 10 years. Movement Disorders, 26(12), 2196-2200. https://doi.org/10.1002/mds.23835

Goldman, J. G., \& Holden, S. (2014). Treatment of Psychosis and Dementia in Parkinson's Disease. Current Treatment Options in Neurology, 16(3), 1-25. https://doi.org/10.1007/s11940-013-0281-2

Goldman, J. G., \& Postuma, R. (2014). Premotor and nonmotor features of Parkinson's disease. Current Opinion in Neurology, 27(4), 434-441. https://doi.org/10.1097/WCO.0000000000000112

Guo, L., Jiang, Y., Yatsuya, H., Yoshida, Y., Sakamoto, J., L., G., ... J., S. (2009). Group education with personal rehabilitation for idiopathic Parkinson's disease. Can J Neurol Sci, 36(1), 51-59. Retrieved from http://www.embase.com/search/results?subaction=viewrecord\&from=export\&id=L 354236533

Hadinia, A., Meyer, A., Bruegger, V., Hatz, F., Nowak, K., Taub, E., ... Gschwandtner, U. (2016). Cognitive Behavioral Group Therapy Reduces Stress and Improves the Quality of Life in Patients with Parkinson's Disease. Front Psychol, 7, 1975. https://doi.org/10.3389/fpsyg.2016.01975

Hayes, S. C. (2004). Acceptance and commitment therapy, relational frame theory, and the third wave of behavioral and cognitive therapies. Behavior Therapy, 35(4), 639-665. https://doi.org/10.1016/S0005-7894(04)80013-3

Heinrichs, N., Hoffman, E. C., \& Hofmann, S. G. (2001). Cognitive-behavioral treatment for social phobia in parkinson's disease: A single-case study. Cogn Behav Pract, 8(4), 328-335. https://doi.org/10.1016/S1077-7229(01)80005-5 
Hofmann, S. G., Asnaani, A., Vonk, I. J. J., Sawyer, A. T., \& Fang, A. (2012). The efficacy of cognitive behavioral therapy: A review of meta-analyses. Cognitive Therapy and Research, 36(5), 427-440. https://doi.org/10.1007/s10608-012-94761

Humbert, M., Findley, J., Hernandez-Con, M., \& Chahine, L. M. (2017). Cognitive behavioral therapy for insomnia in Parkinson's disease: a case series. NPJ Parkinsons Dis, 3, 25. https://doi.org/10.1038/s41531-017-0027-z

Jacobson, N. S., Martell, C., \& Dimidjian, S. (2001). Behavioral Activation Treatment for Depression: Returning to Contextual Roots. Clinical Psychology: Science and Practice, 8(3), 255-270. https://doi.org/10.1093/clipsy/8.3.255

Jiménez-Murcia, S., Bove, F. I., Israel, M., Steiger, H., Fernández-Aranda, F., ÁlvarezMoya, E., ... Menchon, J. M. (2012). Cognitive-behavioral therapy for pathological gambling in Parkinson's disease: a pilot controlled study. Eur Addict Res, 18(6), 265-274. https://doi.org/10.1159/000337442

Kabat-Zinn, J. (2006). Mindfulness-Based Interventions in Context: Past, Present, and Future. Clinical Psychology: Science and Practice, 10(2), 144-156. https://doi.org/10.1093/clipsy.bpg016

Kalia, L. V, \& Lang, A. E. (2015). Parkinson's disease. Lancet, 24(1), 92-98. https://doi.org/10.1016/S0140-6736(14)61393-3

Kampling, H., Brendel, L. K., \& Mittag, O. (2019). (Neuro)psychological interventions for non-motor symptoms in the treatment of patients with Parkinson's disease: A systematic umbrella review. Neuropsychology Review, 29(2), 166-180. https://doi.org/10.1007/s11065-019-09409-4 
Kraepelien, M., Schibbye, R., Månsson, K., Sundström, C., Riggare, S., Andersson, G., ... Kaldo, V. (2020). Individually Tailored Internet-Based Cognitive-Behavioral Therapy for Daily Functioning in Patients with Parkinson's Disease: A Randomized Controlled Trial. Journal of Parkinson's Disease, 10(2), 653-664. https://doi.org/10.3233/JPD-191894

Kwok, J. Y. Y. Y., Kwan, J. C. Y. Y., Auyeung, M., Mok, V. C. T. T., Lau, C. K. Y. Y., Choi, K. C., \& Chan, H. Y. L. L. (2019). Effects of Mindfulness Yoga vs Stretching and Resistance Training Exercises on Anxiety and Depression for People With Parkinson Disease: A Randomized Clinical Trial. JAMA Neurology, 76(7), 755-763. https://doi.org/10.1001/jamaneurol.2019.0534

Lawson, R. A., Millar, D., Brown, R. G., \& Burn, D. J. (2013). Guided self-help for the management of worry in Parkinson's disease: a pilot study. J Parkinsons Dis, 3(1), 61-68. https://doi.org/10.3233/JPD-120156

Lebrun, C., Gély-Nargeot, M. C., Rossignol, A., Geny, C., \& Bayard, S. (2019). Efficacy of cognitive behavioral therapy for insomnia comorbid to Parkinson's disease: A focus on psychological and daytime functioning with a single-case design with multiple baselines. Journal of Clinical Psychology, 76(3), 356-376. https://doi.org/10.1002/jclp.22883

Leroi, I., Ahearn, D. J., Andrews, M., Mcdonald, K. R., Byrne, E. J., \& Burns, A. (2011). Behavioural disorders, disability and quality of life in Parkinson's disease. Age and Ageing, 40(5), 614-621. https://doi.org/10.1093/ageing/afr078

Leroi, I., Baker, P., Kehoe, P., Daniel, E., \& Byrne, E. J. (2010). A pilot randomized controlled trial of sleep therapy in Parkinson's disease: Effect on patients and 
caregivers. International Journal of Geriatric Psychiatry, 25(10), 1073-1079. https://doi.org/10.1002/gps.2472

Leroi, I., Vatter, S., Carter, L.-A. A., Smith, S. J., Orgeta, V., Poliakoff, E., ... McCormick, S. A. (2019). Parkinson's-adapted cognitive stimulation therapy: a pilot randomized controlled clinical trial. Therapeutic Advances In Neurological Disorders, 12, $1756286419852217-1756286419852217$. https://doi.org/10.1177/1756286419852217

Louise, S., Fitzpatrick, M., Strauss, C., Rossell, S. L., \& Thomas, N. (2018). Mindfulness- and acceptance-based interventions for psychosis: Our current understanding and a meta-analysis. Schizophrenia Research, 192, 57-63. https://doi.org/10.1016/j.schres.2017.05.023

Lundervold, D. A., Pahwa, R., \& Lyons, K. E. (2008). Effect of Behavioral Intervention on Comorbid General Anxiety Disorder and Parkinson's Disease. Clin Gerontol, 32(1), 104-117. https://doi.org/10.1080/07317110802468736

Lundervold, D. A., Pahwa, R., \& Lyons, K. E. (2013). Behavioral relaxation training for Parkinson's disease related dyskinesia and comorbid social anxiety. International Journal of Behavioral Consultation and Therapy, 7(4), 1-5. https://doi.org/10.1037/h0100957

Macht, M, Gerlich, C., Ellgring, H., Schradi, M., Rusinol, A. B., Crespo, M., ... Kanarik, E. (2007). Patient education in Parkinson's disease: Formative evaluation of a standardized programme in seven European countries. Patient Educ Couns, 65(2), 245-252. https://doi.org/10.1016/j.pec.2006.08.005

Macht, Michael, Pasqualini, M. S., \& Taba, P. (2007). Cognitive-behavioral Strategies 
for Parkinson's Disease: A Report of Three Cases. J Clin Psychol Med Settings, 14(2), 165-176. https://doi.org/10.1007/s10880-007-9065-8

Mark, M. (2006). Pathogenesis, diagnosis and treatment. In M. Menza \& L. Marsh (Eds.), Psychiatric issues in Parkinson's disease. A practical guide (pp. 1-17). London and New York: Taylor \& Francis.

McCallie, M. S., Blum, C. M., \& Hood, C. J. (2006). Progressive Muscle Relaxation, Journal of Human Behavior in the Social Environment. Progressive Muscle Relaxation, Journal of Human Behavior in the Social Environment, 6(2006), 5166. https://doi.org/10.1300/J137v13n03

McKeith, I. G., \& Burn, D. (2000). Spectrum of Parkinson's disease, Parkinson's dementia, and Lewy body dementia. Neurologic Clinics, 18(4), 865-883. https://doi.org/10.1016/S0733-8619(05)70230-9

Mohlman, J., Reel, D. H., Chazin, D., Ong, D., Georgescu, B., Tiu, J., \& Dobkin, R. D. (2010). A Novel Approach to Treating Anxiety and Enhancing Executive Skills in an Older Adult with Parkinson's Disease. Clin Case Stud, 9(1), 74-90. https://doi.org/10.1177/1534650109351305

Moreno, J. T. (1946). Psychodrama and Group Psychotherapy. Sociometry, 9(2/3), 249253.

Okai, D., Askey-Jones, S., Samuel, M., O’Sullivan, S. S., Chaudhuri, K. R., Martin, A., ... David, A. S. (2013). Trial of CBT for impulse control behaviors affecting Parkinson patients and their caregivers. Neurology, 80(9), 792-799. https://doi.org/10.1212/WNL.0b013e3182840678 
Osawa, C., Kamei, Y., Nozaki, K., Furusawa, Y., \& Murata, M. (2020). Brief Cognitive Behavioral Therapy for Insomnia in Parkinson's Disease: A Case Series Study. Japanese Psychological Research, 1-13. https://doi.org/10.1111/jpr.12287

Parkinson, J. (1817). An essay on the shaking palsy. London: Sherwood, Neely and Jones.

Patel, S., Ojo, O., Genc, G., Oravivattanakul, S., Huo, Y., Rasameesoraj, T., ... Fernandez, H. H. (2017). A Computerized Cognitive behavioral therapy Randomized, Controlled, pilot trial for insomnia in Parkinson Disease (ACCORDPD). Journal of Clinical Movement Disorders, 4(1), 10-16. https://doi.org/10.1186/s40734-017-0062-2

Peters, M., Godfrey, C., McInerney, P., Munn, Z., Tricco, A., \& Khalil, H. (2020). Chapter 11: Scoping Reviews (2020 version). In E. Aromataris \& Z. Munn (Eds.), JBI Manual for Evidence Synthesis (pp. 406-451). JBI. https://doi.org/10.46658/JBIMES-20-12

Pickut, B., Vanneste, S., Hirsch, M. A., Van Hecke, W., Kerckhofs, E., Marien, P., ... Cras, P. (2015). Mindfulness Training among Individuals with Parkinson’s Disease: Neurobehavioral Effects. Parkinsons Dis, 2015, 816404. https://doi.org/10.1155/2015/816404

Reijnders, J. S. A. M., Ehrt, U., Weber, W. E. J., Aarsland, D., \& Leentjens, A. F. G. (2008). A systematic review of prevalence studies of depression in Parkinson's disease. Movement Disorders, 23(2), 183-189. https://doi.org/10.1002/mds.21803

Reynolds, G. O., Saint-Hilaire, M., Thomas, C. A., Barlow, D. H., \& Cronin-Golomb, A. (2019). Cognitive-Behavioral Therapy for Anxiety in Parkinson's Disease. 
Behavior Modification, 145445519838828-145445519838828.

https://doi.org/10.1177/0145445519838828

Richardson, T., \& Marshall, A. (2012). Cognitive behavioural therapy for depression in advanced Parkinson's disease: a case illustration. The Cognitive Behaviour Therapist, 5(2-3), 60-69. https://doi.org/10.1017/s1754470x12000049

Rios Romenets, S., Creti, L., Fichten, C., Bailes, S., Libman, E., Pelletier, A., \& Postuma, R. B. (2013). Doxepin and cognitive behavioural therapy for insomnia in patients with Parkinson's disease - A randomized study. Parkinsonism and Related Disorders, 19(7), 670-675. https://doi.org/10.1016/j.parkreldis.2013.03.003

Rodgers, S. H., Schutze, R., Gasson, N., Anderson, R. A., Kane, R. T., Starkstein, S., ... Egan, S. J. (2019). Modified Mindfulness-Based Cognitive Therapy for Depressive Symptoms in Parkinson's Disease: a Pilot Trial. Behav Cogn Psychother, 47(4), 116. https://doi.org/10.1017/S135246581800070X

Shapiro, F. (2017). Eye movement desensitization and reprocessing (EMDR) therapy: Basic principles, protocols, and procedures (3rd ed.). New York: Guilford Press.

Shinmei, I., Kobayashi, K., Oe, Y., Takagishi, Y., Kanie, A., Ito, M., ... Dobkin, R. D. (2016). Cognitive behavioral therapy for depression in Japanese Parkinson's disease patients: A pilot study. Neuropsychiatric Disease and Treatment, 12, 1319-1331. https://doi.org/10.2147/NDT.S104777

Simpson, J., Chatzidamianos, G., \& Eccles, F. (2015). Parkinson's UK Scale of Perceived Control: Scale construction and initial validation.

Simpson, J., Dale, M., Theed, R., Gunn, S., Zarotti, N., \& Eccles, F. J. R. (2019). 
Validity of irritability in Huntington's disease: A scoping review. Cortex, 120, 353-374. https://doi.org/10.1016/j.cortex.2019.06.012

Simpson, J., Lekwuwa, G., \& Crawford, T. (2013). Illness beliefs and psychological outcome in people with Parkinson's disease - Applied Social Sciences Index and Abstracts (ASSIA) - ProQuest. Chronic Illness, 9(2), 165-176. Retrieved from http://search.proquest.com/assia/docview/1541985753/A88A1D8773094682PQ/65 ?accountid $=9883$

Simpson, J., McMillan, H., \& Reeve, D. (2013). Reformulating psychological difficulties in people with Parkinson's disease: The potential of a social relational approach to disablism. Parkinson's Disease, 2013. https://doi.org/10.1155/2013/608562

Son, H. G., \& Choi, E. O. (2018). The Effects of Mindfulness Meditation-Based Complex Exercise Program on Motor and Nonmotor Symptoms and Quality of Life in Patients with Parkinson's Disease. Asian Nursing Research, 12(2), 145153. https://doi.org/10.1016/j.anr.2018.06.001

Soundy, A., Collett, J., Lawrie, S., Coe, S., Roberts, H., Hu, M., ... Dawes, H. (2019). A Qualitative Study on the Impact of First Steps-A Peer-led Educational Intervention for People Newly Diagnosed with Parkinson's Disease. Behavioral Sciences (2076-328X), 9(10), 107. Retrieved from http://10.0.13.62/bs9100107

Sproesser, E., Viana, M. A., Quagliato, E. M. A. B., \& de Souza, E. A. P. (2010). The effect of psychotherapy in patients with PD: a controlled study. Parkinsonism Relat Disord, 16(4), 298-300. https://doi.org/10.1016/j.parkreldis.2009.08.008

Tiihonen, S., Lankinen, A., \& Viemerö, V. (2012). An Evaluation of a Cognitive- 
Behavioral Patient Education Program for Persons with Parkinson's Disease in Finland. Nordic Psychology, 60(4), 316-331. https://doi.org/10.1027/19012276.60.4.316

Todd, D., Simpson, J., \& Murray, C. (2010). An interpretative phenomenological analysis of delusions in people with Parkinson's disease. Disability and Rehabilitation, 32(15), 1291-1299. https://doi.org/10.3109/09638280903514705

Troeung, L., Egan, S. J., \& Gasson, N. (2014). A waitlist-controlled trial of group cognitive behavioural therapy for depression and anxiety in Parkinson's disease. BMC Psychiatry, 14, 19. https://doi.org/10.1186/1471-244X-14-19

Vandenberg, B. E., Hassed, C., Hester, J., Russell, G., Advocat, J., Enticott, J., ... Russell, G. (2018). Mindfulness-based lifestyle programs for the self-management of Parkinson's disease in Australia. Health Promotion International, 1-9. https://doi.org/10.1093/heapro/day021

Veazey, C., Cook, K. F., Stanley, M., Lai, E. C., \& Kunik, M. E. (2009). Telephoneadministered cognitive behavioral therapy: a case study of anxiety and depression in Parkinson's disease. J Clin Psychol Med Settings, 16(3), 243-253. https://doi.org/10.1007/s10880-009-9167-6

Walsh, J. (2010). Psychoeducation in mental health. Oxford: Oxford Unversity Press.

Weintraub, D., \& Burn, D. J. (2011). Parkinson's disease: The quintessential neuropsychiatric disorder. Movement Disorders, 26(6), 1022-1031. https://doi.org/10.1002/mds.23664

Willis, A. W., Schootman, M., Kung, N., \& Racette, B. A. (2013). Epidemiology and 
neuropsychiatric manifestations of Young Onset Parkinson's Disease in the United States. Parkinsonism and Related Disorders, 19(2), 202-206.

https://doi.org/10.1016/j.parkreldis.2012.09.014

Wuthrich, V. M., \& Rapee, R. M. (2019). Telephone-Delivered Cognitive Behavioural Therapy for Treating Symptoms of Anxiety and Depression in Parkinson's Disease: A Pilot Trial. Clinical Gerontologist, 42(4), 444-453. https://doi.org/10.1080/07317115.2019.1580811

Xie, C. L., Wang, X. D., Chen, J., Lin, H. Z., Chen, Y. H., Pan, J. L., \& Wang, W. W. (2015). A systematic review and meta-analysis of cognitive behavioral and psychodynamic therapy for depression in Parkinson's disease patients. Neurol Sci, 36(6), 833-843. https://doi.org/10.1007/s10072-015-2118-0

Yamanishi, T., Tachibana, H., Oguru, M., Matsui, K., Toda, K., Okuda, B., \& Oka, N. (2013). Anxiety and depression in patients with Parkinson's disease. Internal Medicine, 52(5), 539-545. https://doi.org/10.2169/internalmedicine.52.8617

Yang, H., \& Petrini, M. (2012). Effect of cognitive behavior therapy on sleep disorder in Parkinson's disease in China: a pilot study. Nurs Health Sci, 14(4), 458-463. https://doi.org/10.1111/j.1442-2018.2012.00711.x

Zarotti, N., Coates, E., McGeachan, A., Williams, I., Beever, D., Hackney, G., ... Young, T. (2019). Health care professionals' views on psychological factors affecting nutritional behaviour in people with motor neuron disease: A thematic analysis. British Journal of Health Psychology, 24(4), 953-969. https://doi.org/10.1111/bjhp.12388

Zarotti, N., Dale, M., Eccles, F., \& Simpson, J. (2020). Psychological Interventions for 
People with Huntington's Disease: A Call to Arms. Journal of Huntington's Disease, Preprint(Preprint), 1-13. https://doi.org/10.3233/JHD-200418

Zarotti, N., Mayberry, E., Ovaska-stafford, N., Eccles, F., \& Simpson, J. (2020). Psychological interventions for people with motor neuron disease: a scoping review. Amyotrophic Lateral Sclerosis and Frontotemporal Degeneration, 0(0), 111. https://doi.org/10.1080/21678421.2020.1788094

Zarotti, N., Simpson, J., \& Fletcher, I. (2019). 'I have a feeling I can't speak to anybody': A thematic analysis of communication perspectives in people with Huntington's disease. Chronic Illness, 15(1), 61-73. https://doi.org/10.1177/1742395317733793

Zečević, I. (2020). Clinical practice guidelines based on evidence for cognitivebehavioural therapy in Parkinson's disease comorbidities: A literature review. Clinical Psychology and Psychotherapy, (January), 1-11. https://doi.org/10.1002/cpp.2448

Zhang, Z. X., \& Roman, G. C. (1993). Worldwide occurrence of Parkinson's disease: An updated review. Neuroepidemiology, 12(4), 195-208. https://doi.org/10.1159/000110318 


\section{Tables}

Table 1. Logic grid for search strategy.




Table 2. Overview of adopted search terms and identified items per database.

\section{Search terms}

(Parkinson* disease AND Acceptance and commitment therapy) OR (Parkinson* disease AND Behavio* therapy) OR (Parkinson* disease AND Cognitive analytic therapy) OR (Parkinson* disease AND Cognitive behavio* therapy) OR (Parkinson* disease AND Cognitive therapy) OR (Parkinson* disease AND Compassion* focused therapy) OR (Parkinson* disease AND Counsel*) OR (Parkinson* disease AND Couple* therapy) OR (Parkinson* disease AND Dialectical behavioral therapy) OR (Parkinson* disease AND Emotion focused therapy) OR (Parkinson* disease AND Emotive behavio* therapy) OR (Parkinson* disease AND Eye movement desensiti* and reprocessing) OR (Parkinson* disease AND Family therapy) OR (Parkinson* disease AND Gestalt therapy) OR (Parkinson* disease AND Group* therapy) OR (Parkinson* disease AND Integrative therapy) OR (Parkinson* disease AND Interpersonal therapy) OR (Parkinson* disease AND Meditat*) OR (Parkinson* disease AND Metacognitive therapy) OR (Parkinson* disease AND Mindfulness) OR (Parkinson* disease AND Mindfulness-based cognitive therapy) OR (Parkinson* disease AND Mindfulness-based stress reduction) OR (Parkinson* disease AND Motivational interviewing) OR (Parkinson* disease AND Narrative therapy) OR (Parkinson* disease AND Person cent* therapy) OR (Parkinson* disease AND Psychoanal*) OR (Parkinson* disease AND Psychodynamic therapy) OR (Parkinson* disease AND Psychoeducati*) OR (Parkinson* disease AND Psychological intervention) OR (Parkinson* disease AND Psychotherap*) OR (Parkinson* disease AND Rational emotive behavio* therapy) OR (Parkinson* disease AND Schema therapy) OR (Parkinson* disease AND Self-management) OR (Parkinson* disease AND Solution focused therapy) OR (Parkinson* disease AND Systemic therapy) 
Table 3. Key characteristics of included studies.

\begin{tabular}{|c|c|c|c|c|c|c|c|}
\hline Citation & Category & Design & Sample & Intervention & Relevant outcomes & Relevant measures & Key results \\
\hline \multirow{6}{*}{$\begin{array}{l}\text { Ghielen et } \\
\text { al., } 2017\end{array}$} & \multirow[t]{6}{*}{ ACT } & \multirow[t]{6}{*}{$\mathrm{RCT}$} & $\mathrm{I}: 19$ & \multirow{6}{*}{$\begin{array}{l}\text { Group body } \\
\text { awareness } \\
\text { training }\end{array}$} & Anxiety & $\mathrm{BAl}$ & \multirow{6}{*}{$\begin{array}{l}\text { Significant improvement in emotional } \\
\text { well-being for the intervention group, but } \\
\text { no changes in self-efficacy }\end{array}$} \\
\hline & & & \multirow[t]{5}{*}{ C: 19} & & \multirow[t]{5}{*}{ Self-efficacy } & $\mathrm{BDI}$ & \\
\hline & & & & & & GSES-10 & \\
\hline & & & & & & NEADL index & \\
\hline & & & & & & PDQ-39 & \\
\hline & & & & & & WOQ-19 & \\
\hline \multirow{5}{*}{$\begin{array}{l}\text { Butterfield } \\
\text { et al., } 2017\end{array}$} & \multirow[t]{5}{*}{ BA } & \multirow{5}{*}{$\begin{array}{l}\text { Uncontrolled } \\
\text { pretest- } \\
\text { posttest }\end{array}$} & \multirow[t]{5}{*}{27} & \multirow{5}{*}{$\begin{array}{l}\text { Parkinson's Active } \\
\text { Living (PAL) }\end{array}$} & Apathy & ADLs UPDRS & \multirow{2}{*}{$\begin{array}{l}\text { Large effect of treatment at post- } \\
\text { intervention on apathy severity }\end{array}$} \\
\hline & & & & & Depression & AES-S & \\
\hline & & & & & \multirow[t]{3}{*}{ Quality of life } & GDS & Medium to large effect on depression \\
\hline & & & & & & LARS & Medium effect on quality of life \\
\hline & & & & & & PDQ-39 & $\begin{array}{l}\text { Changes in apathy and depression } \\
\text { maintained at 1-month follow-up }\end{array}$ \\
\hline \multirow{4}{*}{$\begin{array}{l}\text { Lundervold } \\
\text { et al., } 2008\end{array}$} & \multirow[t]{4}{*}{ BRT } & \multirow{4}{*}{$\begin{array}{l}\text { Multiple } \\
\text { baseline single } \\
\text { case } \\
\text { experimental } \\
\text { design }\end{array}$} & \multirow[t]{4}{*}{1} & \multirow[t]{4}{*}{ BRT } & \multirow[t]{4}{*}{ Anxiety } & BRS & \multirow{4}{*}{$\begin{array}{l}\text { Systematic increases in relaxed behaviour } \\
\text { and decreased ratings of distress and } \\
\text { anger at post-intervention, maintained at } \\
\text { follow-up } \\
\text { Further decreases in distress ratings } \\
\text { observed following BRT + imagery and } \\
\text { BRT + coping }\end{array}$} \\
\hline & & & & & & CAS & \\
\hline & & & & & & SUD & \\
\hline & & & & & & & \\
\hline
\end{tabular}




\begin{tabular}{|c|c|c|c|c|c|c|c|}
\hline \multirow{4}{*}{$\begin{array}{l}\text { Lundervold } \\
\text { et al., } 2013\end{array}$} & \multirow[t]{4}{*}{ BRT } & \multirow[t]{4}{*}{ Single case } & \multirow[t]{4}{*}{1} & \multirow{4}{*}{$\begin{array}{l}\text { Behavioral } \\
\text { Relaxation } \\
\text { Training (BRT) - } 4 \\
\text { sessions }\end{array}$} & \multirow[t]{4}{*}{ Anxiety } & AARP & \multirow{3}{*}{$\begin{array}{l}\text { Systematic increases in relaxed behaviour } \\
\text { and decreased ratings of distress and } \\
\text { anger at post-intervention, maintained at } \\
\text { follow-up }\end{array}$} \\
\hline & & & & & & BRS & \\
\hline & & & & & & CAS & \\
\hline & & & & & & SUD & $\begin{array}{l}\text { Participant rated BRT as highly } \\
\text { acceptable }\end{array}$ \\
\hline \multirow{8}{*}{$\begin{array}{l}\text { Berardelli } \\
\text { et al., } 2015\end{array}$} & \multirow[t]{8}{*}{$\mathrm{CBT}$} & \multirow{8}{*}{$\begin{array}{l}\text { Uncontrolled } \\
\text { pretest- } \\
\text { posttest }\end{array}$} & \multirow[t]{8}{*}{7} & \multirow[t]{8}{*}{ Group CBT } & Anxiety & AES & \multirow{8}{*}{$\begin{array}{l}\text { Significant improvements in anxiety, } \\
\text { depression quality of life at post- } \\
\text { intervention }\end{array}$} \\
\hline & & & & & Depression & BPRS & \\
\hline & & & & & \multirow[t]{6}{*}{ Quality of life } & CGI & \\
\hline & & & & & & HAM-A & \\
\hline & & & & & & HAM-D & \\
\hline & & & & & & PDQ8 & \\
\hline & & & & & & SCID-I & \\
\hline & & & & & & SCID-II & \\
\hline \multirow{7}{*}{$\begin{array}{l}\text { Berardelli } \\
\text { et al., } 2018\end{array}$} & \multirow[t]{7}{*}{$\mathrm{CBT}$} & \multirow{7}{*}{$\begin{array}{l}\text { Quasi- } \\
\text { experiment }\end{array}$} & I: 9 & \multirow[t]{7}{*}{ Group CBT } & Anxiety & BPRS & \multirow{7}{*}{$\begin{array}{l}\text { Significant improvements in anxiety, } \\
\text { depression, and apathy for the CBT group } \\
\text { at post-intervention }\end{array}$} \\
\hline & & & C: 9 & & Apathy & CGI & \\
\hline & & & & & Depression & HAM-A & \\
\hline & & & & & \multirow[t]{4}{*}{ Quality of life } & HAM-D & \\
\hline & & & & & & PDQL & \\
\hline & & & & & & SCID-I & \\
\hline & & & & & & UPDRS & \\
\hline \multirow{2}{*}{$\begin{array}{l}\text { Calleo et } \\
\text { al., } 2015\end{array}$} & \multirow[t]{2}{*}{ CBT } & \multirow[t]{2}{*}{$\mathrm{RCT}$} & I: 10 & \multirow{2}{*}{$\begin{array}{l}\text { CBT } \\
\text { (administered } \\
\text { either by }\end{array}$} & Anxiety & SIGH-A & \multirow{2}{*}{$\begin{array}{l}\text { High effect sizes for treatment at 1- } \\
\text { month follow-up for both anxiety and }\end{array}$} \\
\hline & & & C: 10 & & Depression & SIGH-D & \\
\hline
\end{tabular}




\begin{tabular}{|c|c|c|c|c|c|c|c|}
\hline & & & & $\begin{array}{l}\text { telephone or in } \\
\text { person) }\end{array}$ & & & $\begin{array}{l}\text { depression, but only depression reached } \\
\text { significance }\end{array}$ \\
\hline \multirow{5}{*}{$\begin{array}{l}\text { Cole \& } \\
\text { Vaughan, } \\
2005\end{array}$} & \multirow[t]{5}{*}{ CBT } & \multirow[t]{5}{*}{ Case series } & \multirow[t]{5}{*}{5} & \multirow{5}{*}{$\begin{array}{l}\text { Individual CBT } \\
\text { delivered at home }\end{array}$} & \multirow{5}{*}{$\begin{array}{l}\text { Depression } \\
\text { Quality of life }\end{array}$} & BDI-II & \multirow{3}{*}{$\begin{array}{l}\text { Clinically reliable reduction of depression } \\
\text { in } 4 \text { participants, with greater } \\
\text { improvement reported by the } 2 \\
\text { participants with more severe baseline } \\
\text { depression }\end{array}$} \\
\hline & & & & & & $\begin{array}{l}\text { Estimate of daily } \\
\text { activities }\end{array}$ & \\
\hline & & & & & & GDS & \\
\hline & & & & & & PDQL & \multirow[t]{2}{*}{ No change in quality of life } \\
\hline & & & & & & $\begin{array}{l}\text { Visual analogue } \\
\text { scale for mood }\end{array}$ & \\
\hline \multirow{6}{*}{$\begin{array}{l}\text { Dissanayak } \\
\text { a et al., } \\
2017\end{array}$} & \multirow[t]{6}{*}{$\mathrm{CBT}$} & \multirow{6}{*}{$\begin{array}{l}\text { Uncontrolled } \\
\text { pretest- } \\
\text { posttest }\end{array}$} & \multirow[t]{6}{*}{12} & \multirow{6}{*}{$\begin{array}{l}\text { Manualised and } \\
\text { CBT for anxiety in } \\
\text { PD }\end{array}$} & Anxiety & GAI & \multirow{6}{*}{$\begin{array}{l}\text { Significant improvements in anxiety at } \\
\text { post-intervention, maintained at both 3- } \\
\text { month and 6-month follow-ups } \\
\text { Depression improvements observed only } \\
\text { at 3-month. }\end{array}$} \\
\hline & & & & & \multirow[t]{5}{*}{ Depression } & GDS & \\
\hline & & & & & & HAM-A & \\
\hline & & & & & & HAM-D & \\
\hline & & & & & & PDQL & \\
\hline & & & & & & StAS & \\
\hline \multirow{6}{*}{$\begin{array}{l}\text { Dobkin et } \\
\text { al., } 2006\end{array}$} & \multirow[t]{6}{*}{ CBT } & \multirow[t]{6}{*}{ Case series } & \multirow[t]{6}{*}{3} & \multirow[t]{6}{*}{ CBT intervention } & Anxiety & AIFQ & \multirow{3}{*}{$\begin{array}{l}\text { Meaningful reductions reported in } \\
\text { depressive symptoms over the course of } \\
\text { treatment, and maintained at 1-month } \\
\text { follow-up }\end{array}$} \\
\hline & & & & & \multirow[t]{5}{*}{ Depression } & BDI & \\
\hline & & & & & & HAM-D & \\
\hline & & & & & & IQ & \multirow{2}{*}{$\begin{array}{l}\text { Notable decrease in negative and suicidal } \\
\text { thoughts }\end{array}$} \\
\hline & & & & & & STAI & \\
\hline & & & & & & & Only minimal changes in anxiety \\
\hline
\end{tabular}




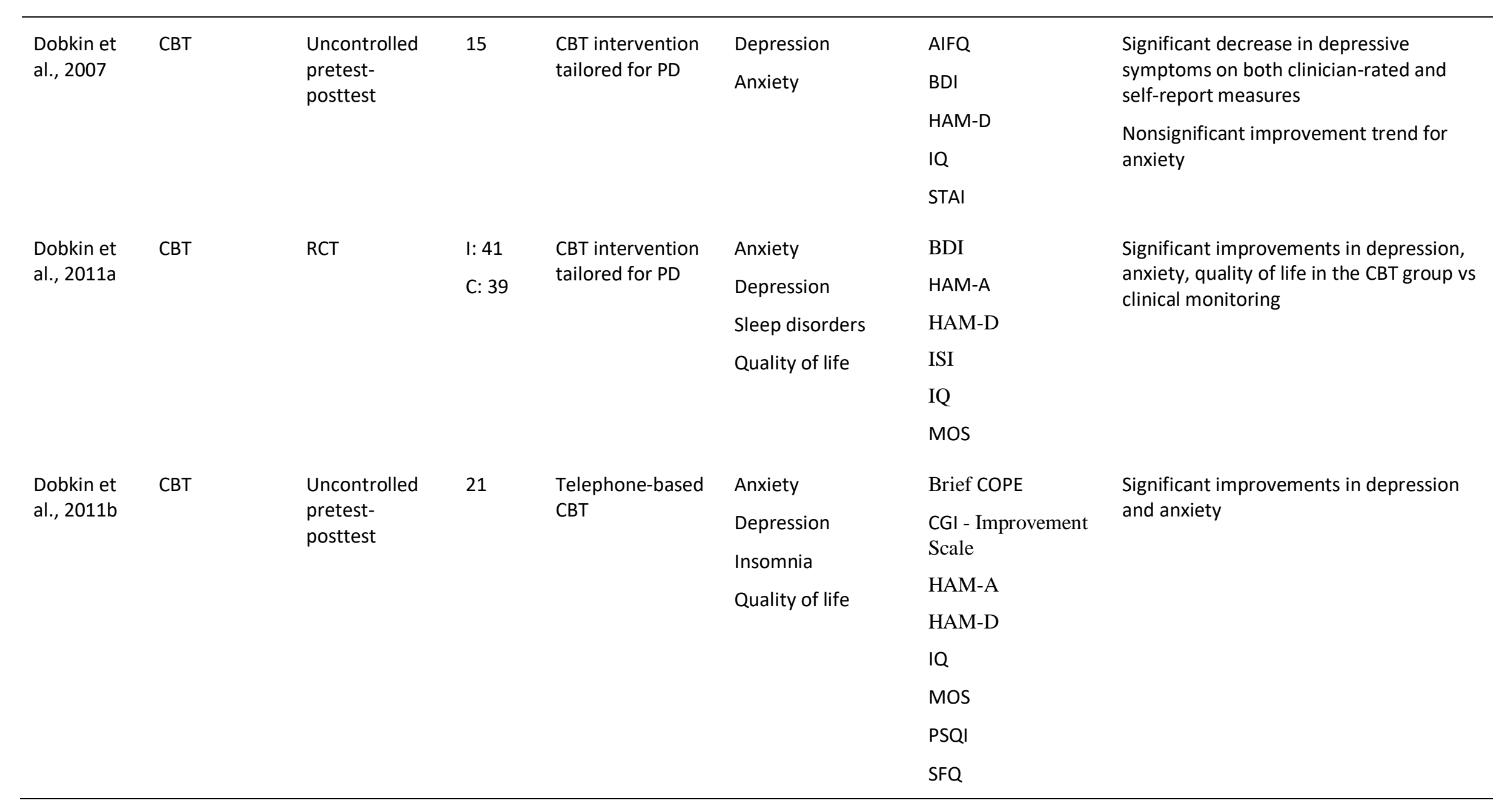




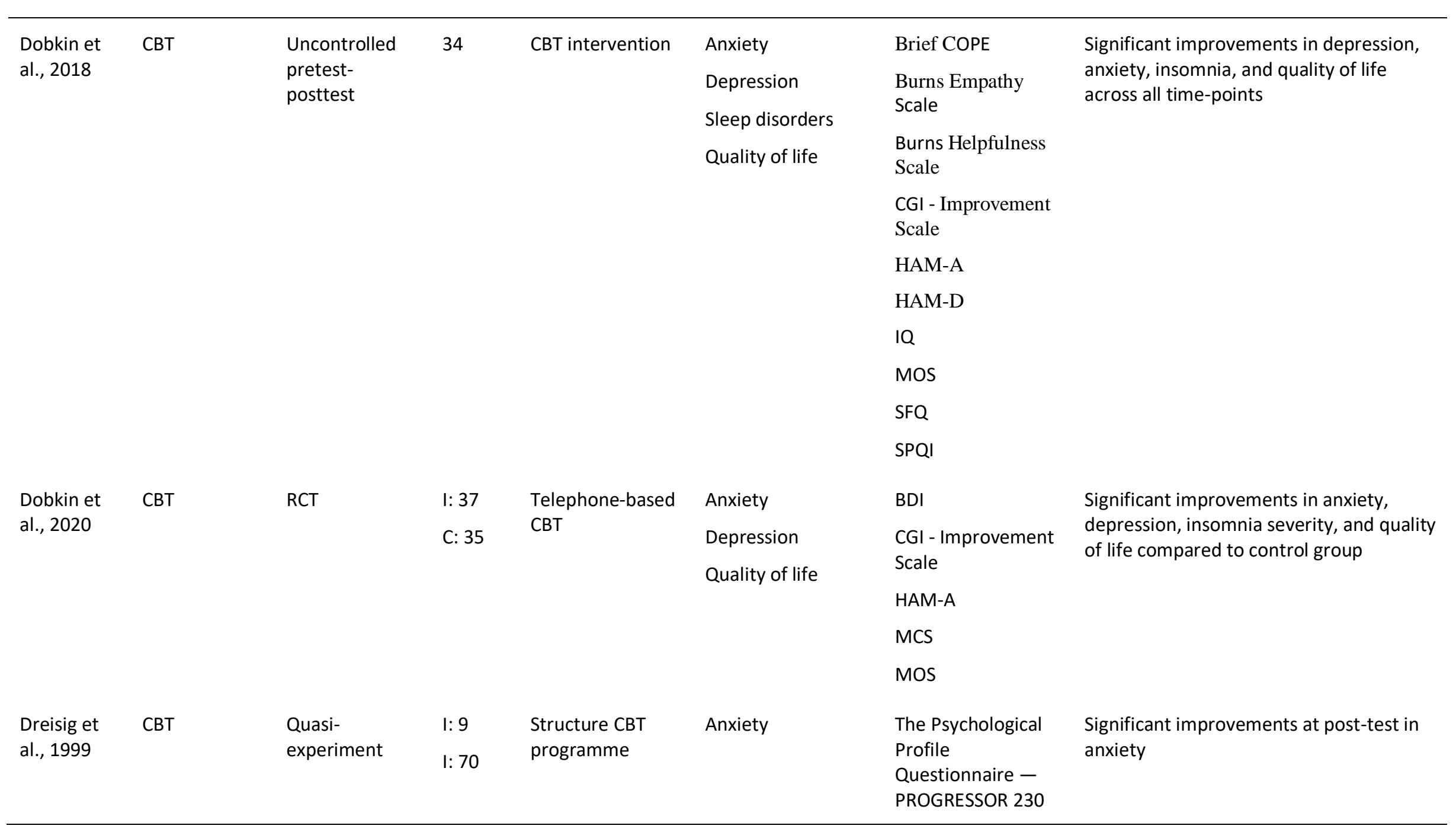




\begin{tabular}{|c|c|c|c|c|c|c|c|}
\hline \multirow[t]{10}{*}{$\begin{array}{l}\text { Farabaugh } \\
\text { et al., } 2010\end{array}$} & CBT & Case series & 8 & CBT & Depression & ADL Scale & \multirow{2}{*}{$\begin{array}{l}\text { Significant linear decrease in mean } \\
\text { depression scores over Weeks } 0 \text { to } 12 \\
57 \% \text { of patients met criteria for remission } \\
\text { at endpoint }\end{array}$} \\
\hline & & & & & \multirow{9}{*}{ Quality of life } & $\begin{array}{l}\text { CGI - Improvement } \\
\text { Scale }\end{array}$ & \\
\hline & & & & & & $\begin{array}{l}\text { CGI-Impressions- } \\
\text { Severity scale }\end{array}$ & \\
\hline & & & & & & DAS & \\
\hline & & & & & & HAM-D & \\
\hline & & & & & & $\begin{array}{l}\text { Mood Module of } \\
\text { SCID-I }\end{array}$ & \\
\hline & & & & & & PSS & \\
\hline & & & & & & Schwab-England & \\
\hline & & & & & & SF-36 & \\
\hline & & & & & & SQ & \\
\hline \multirow{3}{*}{$\begin{array}{l}\text { Feeney et } \\
\text { al., } 2005\end{array}$} & \multirow[t]{3}{*}{ CBT } & \multirow[t]{3}{*}{ Case series } & \multirow[t]{3}{*}{4} & \multirow[t]{3}{*}{ Group CBT } & Anxiety & BDI-II & \multirow{2}{*}{$\begin{array}{l}\text { Clinically significant improvement in } \\
\text { depression in three out of the four } \\
\text { participants }\end{array}$} \\
\hline & & & & & \multirow[t]{2}{*}{ Depression } & STAI-S & \\
\hline & & & & & & & $\begin{array}{l}\text { No clinically significant improvement in } \\
\text { anxiety }\end{array}$ \\
\hline \multirow{5}{*}{$\begin{array}{l}\text { Hadinia et } \\
\text { al., } 2016\end{array}$} & \multirow{5}{*}{ CBT } & \multirow{5}{*}{ RCT } & I: 16 & \multirow{5}{*}{ Group CBT } & Anxiety & AES & \multirow{5}{*}{$\begin{array}{l}\text { Significantly greater improvement for the } \\
\text { CBT group in quality of life }\end{array}$} \\
\hline & & & C: 14 & & Depression & BAI & \\
\hline & & & & & Quality of life & BDI-II & \\
\hline & & & & & \multirow[t]{2}{*}{ Sleep disorders } & BELA-P-k & \\
\hline & & & & & & ESS & \\
\hline
\end{tabular}




\begin{tabular}{|c|c|c|c|c|c|c|c|}
\hline \multirow{3}{*}{$\begin{array}{l}\text { Jiménez- } \\
\text { Murcia et } \\
\text { al., } 2012\end{array}$} & \multirow[t]{3}{*}{ CBT } & \multirow{3}{*}{$\begin{array}{l}\text { Quasi- } \\
\text { experiment }\end{array}$} & I: 15 & \multirow[t]{3}{*}{ CBT } & \multirow[t]{3}{*}{ Impulse control } & GSI & \multirow{3}{*}{$\begin{array}{l}\text { No significant differences between } \\
\text { groups }\end{array}$} \\
\hline & & & \multirow[t]{2}{*}{ C: 45} & & & SCL-90-R & \\
\hline & & & & & & SOGS & \\
\hline \multirow{5}{*}{$\begin{array}{l}\text { Kraepelien } \\
\text { et al., } 2020\end{array}$} & \multirow[t]{5}{*}{ CBT } & \multirow[t]{5}{*}{$\mathrm{RCT}$} & I: 38 & \multirow{5}{*}{$\begin{array}{l}\text { Tailored internet- } \\
\text { based CBT }\end{array}$} & Anxiety & IUS & \multirow{2}{*}{$\begin{array}{l}\text { Significant improvements in anxiety, } \\
\text { depression, insomnia severity, and quality } \\
\text { of life compared to controls }\end{array}$} \\
\hline & & & \multirow[t]{4}{*}{ C: 39} & & Depression & MCQ-30 & \\
\hline & & & & & Sleep disorders & PDQ-39 & Medium effect size for depression, but \\
\hline & & & & & Quality of life & PSWQ & $\begin{array}{l}\text { significantly lower compared to face to } \\
\text { face studies }\end{array}$ \\
\hline & & & & & & & $\begin{array}{l}\text { Significant effects for anxiety not } \\
\text { accompanied by significant improvement } \\
\text { within-group, suggesting the effect could } \\
\text { be partly explained by deterioration in } \\
\text { the control group }\end{array}$ \\
\hline \multirow{7}{*}{$\begin{array}{l}\text { Lawson et } \\
\text { al., } 2013\end{array}$} & \multirow[t]{7}{*}{ CBT } & \multirow[t]{7}{*}{$\mathrm{RCT}$} & \multirow{7}{*}{$\begin{array}{l}\text { I: } 15 \\
\text { C: } 17\end{array}$} & \multirow{7}{*}{$\begin{array}{l}\text { CBT-based self- } \\
\text { help guided } \\
\text { reading resource }\end{array}$} & Anxiety & $\mathrm{BBQ}$ & \multirow{7}{*}{$\begin{array}{l}\text { Significant reductions observed only for } \\
\text { worry and intolerance of uncertainty }\end{array}$} \\
\hline & & & & & Quality of life & $\begin{array}{l}\text { CGI - Impression - } \\
\text { Severity Scale }\end{array}$ & \\
\hline & & & & & & CGI-Improvement & \\
\hline & & & & & & IUS & \\
\hline & & & & & & MCQ-30 & \\
\hline & & & & & & PDQ-39 & \\
\hline & & & & & & PSWQ & \\
\hline \multirow{2}{*}{$\begin{array}{l}\text { Lebrun et } \\
\text { al., } 2019\end{array}$} & \multirow[t]{2}{*}{ CBT } & \multirow{2}{*}{$\begin{array}{l}\text { Multiple } \\
\text { baseline single } \\
\text { case }\end{array}$} & \multirow[t]{2}{*}{15} & \multirow[t]{2}{*}{$\mathrm{CBTi}$} & Anxiety & BDI-II & \multirow{2}{*}{$\begin{array}{l}\text { Significant improvements on insomnia, } \\
\text { anxiety, depression, QoL at post- }\end{array}$} \\
\hline & & & & & Depression & CSD-E & \\
\hline
\end{tabular}




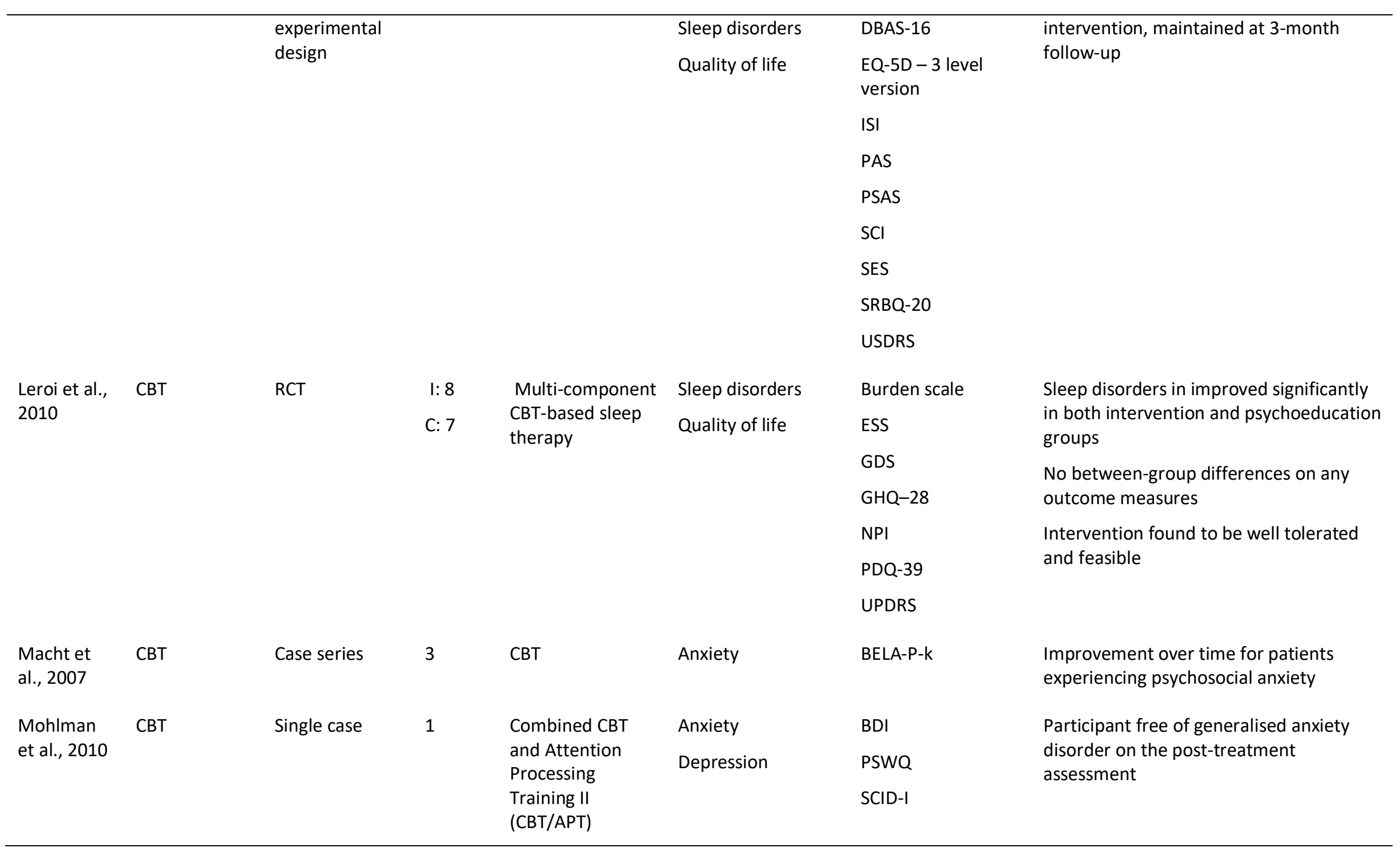




\begin{tabular}{|c|c|c|c|c|c|c|c|}
\hline & & & & & & $\begin{array}{l}\text { SIGH-A } \\
\text { SIGH-D }\end{array}$ & $\begin{array}{l}\text { Considerable reduction in scores on all } \\
\text { anxiety measures from pre- to } \\
\text { posttreatment (no significance reported) }\end{array}$ \\
\hline & & & & & & SIAI & $\begin{array}{l}\text { Reductions in symptoms of depression } \\
\text { (no significance reported) }\end{array}$ \\
\hline \multirow{6}{*}{$\begin{array}{l}\text { Okai et al., } \\
2013\end{array}$} & \multirow[t]{6}{*}{ CBT } & \multirow[t]{6}{*}{$\mathrm{RCT}$} & I: 28 & \multirow{6}{*}{$\begin{array}{l}\text { CBT based on a } \\
\text { treatment manual } \\
\text { compiled during } \\
\text { the pilot phase of } \\
\text { the trial }\end{array}$} & Anxiety & BAI & \multirow{6}{*}{$\begin{array}{l}\text { Frequency and impact of impulse control } \\
\text { disorders significantly reduced over the 6- } \\
\text { month period in the treatment group } \\
\text { CBT plus standard medical care appears } \\
\text { to be more effective than standard } \\
\text { medical care alone in reducing the } \\
\text { severity of impulse control disorders in } \\
\text { PwPpeople with PD }\end{array}$} \\
\hline & & & C: 17 & & Depression & $\mathrm{BDI}$ & \\
\hline & & & & & Impulse control & & \\
\hline & & & & & & $\mathrm{GHQ}-28$ & \\
\hline & & & & & & $\begin{array}{l}\text { Impulse Control } \\
\text { Behavior Severity } \\
\text { Scale (ad-hoc) }\end{array}$ & \\
\hline & & & & & & NPI & \\
\hline \multirow{4}{*}{$\begin{array}{l}\text { Osawa et } \\
\text { al., } 2020\end{array}$} & \multirow[t]{4}{*}{ CBT } & \multirow[t]{4}{*}{ Case series } & \multirow[t]{4}{*}{11} & \multirow[t]{4}{*}{ Brief CBTi } & Quality of life & ISI & \multirow{4}{*}{$\begin{array}{l}\text { Objective sleep measured by actigraph } \\
\text { did not improve, subjective sleep } \\
\text { measured by sleep diary improved } \\
\text { No significant changes in quality of life }\end{array}$} \\
\hline & & & & & Sleep disorders & PDSS & \\
\hline & & & & & & SF-36 & \\
\hline & & & & & & Sleep diaries & \\
\hline \multirow{6}{*}{$\begin{array}{l}\text { Patel et al., } \\
2017\end{array}$} & \multirow[t]{6}{*}{ CBT } & \multirow[t]{6}{*}{$\mathrm{RCT}$} & I: 14 & \multirow{6}{*}{$\begin{array}{l}\text { Computerised } \\
\text { CBTi }\end{array}$} & Quality of life & ESS & \multirow{2}{*}{$\begin{array}{l}\text { Significantly greater improvements in } \\
\text { insomnia scores for CBTi group }\end{array}$} \\
\hline & & & \multirow[t]{5}{*}{ C: 14} & & Sleep disorders & FSS & \\
\hline & & & & & & ISI & \multirow{4}{*}{$\begin{array}{l}\text { Change was not significant at intention- } \\
\text { to-treat analysis likely due to the high } \\
\text { dropout rate in the CBTi group ( } 43 \%)\end{array}$} \\
\hline & & & & & & PDQ-8 & \\
\hline & & & & & & PHQ-9 & \\
\hline & & & & & & PIRS20 & \\
\hline
\end{tabular}




\begin{tabular}{|c|c|c|c|c|c|c|c|}
\hline \multirow{8}{*}{$\begin{array}{l}\text { Reynolds et } \\
\text { al., } 2019\end{array}$} & \multirow[t]{8}{*}{ CBT } & \multirow{8}{*}{$\begin{array}{l}\text { Multiple } \\
\text { baseline single } \\
\text { case } \\
\text { experimental } \\
\text { design }\end{array}$} & \multirow[t]{8}{*}{9} & \multirow{8}{*}{$\begin{array}{l}\text { CBT by } \\
\text { videoconferencin } \\
\text { g or in person }\end{array}$} & \multirow{8}{*}{$\begin{array}{l}\text { Anxiety } \\
\text { Depression }\end{array}$} & ADIS-5 & \multirow{4}{*}{$\begin{array}{l}\text { Significant reductions in anxiety and/or } \\
\text { depression observed in seven out of nine } \\
\text { participants at post-treatment } \\
\text { Most improvements maintained at 6- } \\
\text { week follow-up }\end{array}$} \\
\hline & & & & & & & \\
\hline & & & & & & BAI & \\
\hline & & & & & & BDI-II & \\
\hline & & & & & & GDS & \multirow{4}{*}{$\begin{array}{l}\text { High adherence, retention, as well as } \\
\text { treatment satisfaction and acceptability }\end{array}$} \\
\hline & & & & & & OASIS & \\
\hline & & & & & & ODSIS & \\
\hline & & & & & & STAI & \\
\hline \multirow{3}{*}{$\begin{array}{l}\text { Richardson } \\
\text { \& Marshall, } \\
2012\end{array}$} & \multirow[t]{3}{*}{ CBT } & \multirow[t]{3}{*}{ Single case } & \multirow[t]{3}{*}{1} & \multirow{3}{*}{$\begin{array}{l}\text { CBT for } \\
\text { depression }\end{array}$} & \multirow{3}{*}{$\begin{array}{l}\text { Anxiety } \\
\text { Depression }\end{array}$} & CORE-10 & \multirow{3}{*}{$\begin{array}{l}\text { Reported improvements in global menta } \\
\text { health and moderate reductions in } \\
\text { depression } \\
\text { No effect on anxiety }\end{array}$} \\
\hline & & & & & & GDS & \\
\hline & & & & & & HADS & \\
\hline \multirow{10}{*}{$\begin{array}{l}\text { Rios } \\
\text { Romenets } \\
\text { et al., } 2013\end{array}$} & \multirow[t]{10}{*}{$\mathrm{CBT}$} & \multirow[t]{10}{*}{$\mathrm{RCT}$} & \multirow{10}{*}{$\begin{array}{l}\text { I: } 6 \\
\text { C: } 6\end{array}$} & \multirow[t]{10}{*}{$\mathrm{CBTi}$} & Depression & $\mathrm{BDI}$ & \multirow{4}{*}{$\begin{array}{l}\text { Significant improvement in insomnia } \\
\text { severity scores in the CBTi group, but no } \\
\text { change in night-time sleep score } \\
\text { Clinician-rate clinical global impression } \\
\text { improved significantly }\end{array}$} \\
\hline & & & & & Fatigue & CGI - Change scale & \\
\hline & & & & & \multirow{8}{*}{$\begin{array}{l}\text { Quality of life } \\
\text { Sleep disorders }\end{array}$} & Daily sleep diary & \\
\hline & & & & & & DBAS-16) & \\
\hline & & & & & & ESS & \\
\hline & & & & & & ISI & \\
\hline & & & & & & PDQ-39 & \\
\hline & & & & & & PDSS & \\
\hline & & & & & & PSQI & \\
\hline & & & & & & $\begin{array}{l}\text { SCOPA sleep (PD- } \\
\text { specific) }\end{array}$ & \\
\hline
\end{tabular}




\begin{tabular}{|c|c|c|c|c|c|c|c|}
\hline \multirow[t]{5}{*}{$\begin{array}{l}\text { Shinmei et } \\
\text { al., } 2016\end{array}$} & \multirow[t]{5}{*}{ CBT } & \multirow[t]{5}{*}{$\begin{array}{l}\text { Uncontrolled } \\
\text { pretest- } \\
\text { posttest }\end{array}$} & \multirow[t]{5}{*}{19} & \multirow[t]{5}{*}{$\begin{array}{l}\text { CBT program } \\
\text { using manga } \\
\text { workbooks }\end{array}$} & $\begin{array}{l}\text { Anxiety } \\
\text { Depression }\end{array}$ & $\begin{array}{l}\text { BDI-II } \\
\text { GRID-HAMD }\end{array}$ & \multirow[t]{5}{*}{$\begin{array}{l}\text { Significant improvements in depression at } \\
\text { post-intervention, maintained at 3-month } \\
\text { follow-up }\end{array}$} \\
\hline & & & & & Quality of life & HADS & \\
\hline & & & & & & MOS & \\
\hline & & & & & & OASIS & \\
\hline & & & & & & STAI & \\
\hline \multirow{5}{*}{$\begin{array}{l}\text { Tiihonen et } \\
\text { al., } 2012\end{array}$} & \multirow[t]{5}{*}{ CBT } & \multirow{5}{*}{$\begin{array}{l}\text { Quasi- } \\
\text { experiment }\end{array}$} & I: 29 & \multirow{5}{*}{$\begin{array}{l}\text { CBT patient } \\
\text { education } \\
\text { program } \\
\text { (EduPark) }\end{array}$} & Depression & ADL of UPDRS & \multirow{5}{*}{$\begin{array}{l}\text { Significantly improved quality of life for } \\
\text { treatment group at post-intervention } \\
\text { No significant differences in depression } \\
\text { Good acceptance from participants }\end{array}$} \\
\hline & & & C: 23 & & Quality of life & BELA-P-k & \\
\hline & & & & & & Mood (analogue) & \\
\hline & & & & & & PDQ-39 & \\
\hline & & & & & & SDS & \\
\hline \multirow{5}{*}{$\begin{array}{l}\text { Troeung et } \\
\text { al., } 2014\end{array}$} & \multirow[t]{5}{*}{ CBT } & \multirow[t]{5}{*}{ RCT } & I: 11 & \multirow[t]{5}{*}{ Group CBT } & Anxiety & $\mathrm{CCL}$ & \multirow{2}{*}{$\begin{array}{l}\text { Significant improvement at post- } \\
\text { intervention for CBT group in anxiety and } \\
\text { depression, but no differences in stress. }\end{array}$} \\
\hline & & & $\mathrm{C}: 7$ & & Depression & DASS & \\
\hline & & & & & \multirow{3}{*}{$\begin{array}{l}\text { Quality of life } \\
\text { Stress }\end{array}$} & PDQ-39 & \multirow{2}{*}{$\begin{array}{l}\text { Significant and large effects for } \\
\text { depression, anxiety, and stress at both 1- } \\
\text { month and 6-month follow-ups }\end{array}$} \\
\hline & & & & & & & \\
\hline & & & & & & & $\begin{array}{l}\text { No significant differences for quality of } \\
\text { life over the whole study }\end{array}$ \\
\hline
\end{tabular}




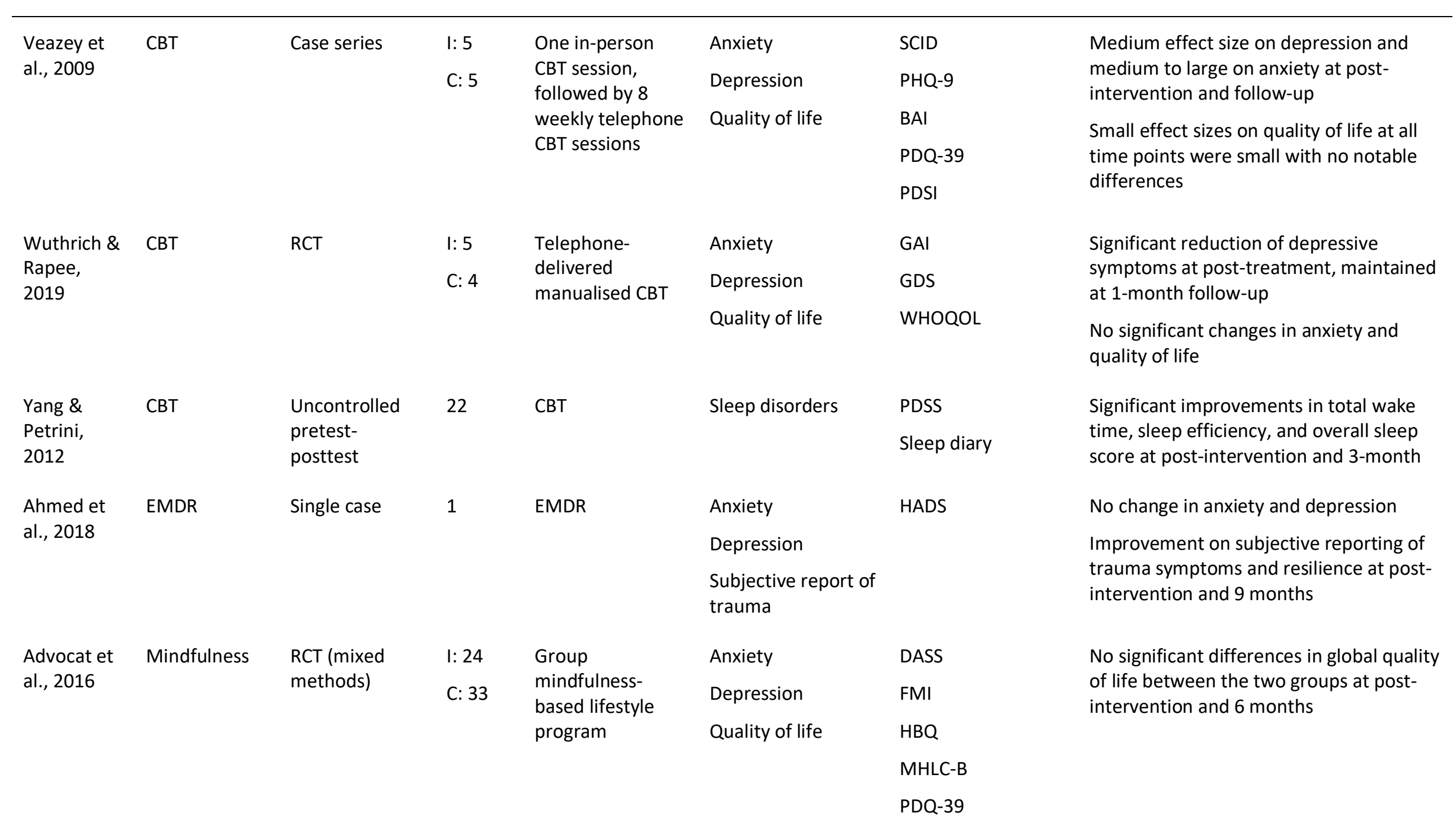




\begin{tabular}{|c|c|c|c|c|c|c|c|}
\hline \multirow[t]{2}{*}{$\begin{array}{l}\text { Birtwell et } \\
\text { al., } 2017\end{array}$} & \multirow[t]{2}{*}{ Mindfulness } & \multirow[t]{2}{*}{$\begin{array}{l}\text { Uncontrolled } \\
\text { pretest- } \\
\text { posttest }\end{array}$} & \multirow[t]{2}{*}{6} & & $\begin{array}{l}\text { Anxiety } \\
\text { Depression }\end{array}$ & $\begin{array}{l}\text { DASS } \\
\text { MAAS }\end{array}$ & $\begin{array}{l}\text { Significant improvements in levels of } \\
\text { depression and anxiety at both post- } \\
\text { intervention and follow-up }\end{array}$ \\
\hline & & & & & Quality of life & PDQ39 & No significant difference in quality of life \\
\hline \multirow{4}{*}{$\begin{array}{l}\text { Cash et al., } \\
2015\end{array}$} & \multirow[t]{4}{*}{ Mindfulness } & \multirow{4}{*}{$\begin{array}{l}\text { Uncontrolled } \\
\text { pretest- } \\
\text { posttest }\end{array}$} & \multirow[t]{4}{*}{29} & \multirow{4}{*}{$\begin{array}{l}\text { MBSR group } \\
\text { intervention }\end{array}$} & Anxiety & AS & Significant reductions in depression \\
\hline & & & & & Depression & GAD-7 & No significant changes in anxiety \\
\hline & & & & & & PDQL & \\
\hline & & & & & & PHQ-9 & \\
\hline \multirow{6}{*}{$\begin{array}{l}\text { Dissanayak } \\
\text { a et al., } \\
2016\end{array}$} & \multirow[t]{6}{*}{ Mindfulness } & \multirow{6}{*}{$\begin{array}{l}\text { Uncontrolled } \\
\text { pretest- } \\
\text { posttest }\end{array}$} & \multirow[t]{6}{*}{14} & \multirow{6}{*}{$\begin{array}{l}\text { Manualised group } \\
\text { mindfulness } \\
\text { intervention } \\
\text { tailored for } \\
\text { PwPpeople with } \\
\text { PD }\end{array}$} & Anxiety & FFMQ & \multirow{6}{*}{$\begin{array}{l}\text { Significant reduction in anxiety, } \\
\text { depression, and quality of life at post- } \\
\text { intervention, not maintained at follow-up } \\
\text { (smaller sample due to attrition) }\end{array}$} \\
\hline & & & & & Depression & GAI & \\
\hline & & & & & Quality of life & HAM-D & \\
\hline & & & & & & OQ-45 & \\
\hline & & & & & & PDQL & \\
\hline & & & & & & UPDRS & \\
\hline $\begin{array}{l}\text { Fitzpatrick } \\
\text { et al., } 2010\end{array}$ & Mindfulness & $\begin{array}{l}\text { Qualitative } \\
\text { evaluation }\end{array}$ & 12 & MBCT course & N/A & N/A & $\begin{array}{l}\text { MBCT could benefit people with PD and } \\
\text { was an acceptable form of group } \\
\text { intervention. }\end{array}$ \\
\hline \multirow{4}{*}{$\begin{array}{l}\text { Kwok et al., } \\
2019\end{array}$} & \multirow[t]{4}{*}{ Mindfulness } & \multirow[t]{4}{*}{$\mathrm{RCT}$} & \multirow{4}{*}{$\begin{array}{l}\text { I: } 71 \\
\text { C: } 67\end{array}$} & \multirow{4}{*}{$\begin{array}{l}\text { Mindfulness Yoga } \\
\text { for PD }\end{array}$} & Anxiety & HADS & \multirow{4}{*}{$\begin{array}{l}\text { Significant better outcomes for the } \\
\text { mindfulness yoga group in anxiety, } \\
\text { depression, and QoL at both post- } \\
\text { intervention and follow-up. }\end{array}$} \\
\hline & & & & & Depression & HWS & \\
\hline & & & & & Quality of life & PDQ-8 & \\
\hline & & & & & & UPDRS & \\
\hline
\end{tabular}




\begin{tabular}{|c|c|c|c|c|c|c|c|}
\hline $\begin{array}{l}\text { Pickut et } \\
\text { al., } 2015\end{array}$ & Mindfulness & $\mathrm{RCT}$ & $\begin{array}{l}\text { I: } 14 \\
\text { C: } 13\end{array}$ & $\begin{array}{l}\text { Mindfulness- } \\
\text { based } \\
\text { intervention }\end{array}$ & $\begin{array}{l}\text { Depression } \\
\text { Quality of Life }\end{array}$ & $\begin{array}{l}\text { BDI } \\
\text { FFMQ } \\
\text { PDQ-39 } \\
\text { UPDRS }\end{array}$ & $\begin{array}{l}\text { Significant improvement for the } \\
\text { intervention group in mindfulness levels. } \\
\text { No significant differences for depression } \\
\text { and QoL }\end{array}$ \\
\hline $\begin{array}{l}\text { Rodgers et } \\
\text { al., } 2019\end{array}$ & Mindfulness & $\mathrm{RCT}$ & $\begin{array}{l}\mathrm{I}: 15 \\
\mathrm{C}: 12\end{array}$ & Modified MBCT & $\begin{array}{l}\text { Anxiety } \\
\text { Depression } \\
\text { Quality of life }\end{array}$ & $\begin{array}{l}\text { DASS } \\
\text { GAI } \\
\text { GDS } \\
\text { PDQ-39 }\end{array}$ & $\begin{array}{l}\text { Significant reduction in depressive } \\
\text { symptoms for the MBCT participants at } \\
\text { both group and individual levels at post- } \\
\text { intervention. No significant effect on } \\
\text { anxiety or quality of life at the group level }\end{array}$ \\
\hline $\begin{array}{l}\text { Son \& Choi, } \\
2018\end{array}$ & Mindfulness & $\mathrm{RCT}$ & $\begin{array}{l}\text { I: } 33 \\
\text { C: } 30\end{array}$ & $\begin{array}{l}\text { Mindfulness } \\
\text { meditation-based } \\
\text { complex exercise } \\
\text { program } \\
\text { (MMBCEP) }\end{array}$ & $\begin{array}{l}\text { Anxiety } \\
\text { Depression } \\
\text { Quality of life }\end{array}$ & $\begin{array}{l}\text { ADL } \\
\text { GDS } \\
\text { PDQL } \\
\text { PDSS } \\
\text { STAI }\end{array}$ & $\begin{array}{l}\text { Significant improvements for quality of } \\
\text { life, anxiety and depression }\end{array}$ \\
\hline $\begin{array}{l}\text { Vandenber } \\
\text { g et al., } \\
2018\end{array}$ & Mindfulness & $\begin{array}{l}\text { Qualitative } \\
\text { evaluation of } \\
\text { Advocat et al., } \\
2016\end{array}$ & 16 & $\begin{array}{l}\text { Group } \\
\text { mindfulness- } \\
\text { based lifestyle } \\
\text { program }\end{array}$ & $\mathrm{N} / \mathrm{A}$ & N/A & $\begin{array}{l}\text { Reported improved feelings of control, } \\
\text { acceptance of disease progression, social } \\
\text { relationships, and self-confidence in } \\
\text { managing the disease. }\end{array}$ \\
\hline $\begin{array}{l}\text { Sproesser } \\
\text { et al., } 2010\end{array}$ & Psychodrama & $\mathrm{RCT}$ & $\begin{array}{l}\text { I: } 8 \\
\text { C: } 8\end{array}$ & $\begin{array}{l}\text { Group } \\
\text { psychotherapy } \\
\text { based on } \\
\text { psychodrama }\end{array}$ & $\begin{array}{l}\text { Anxiety } \\
\text { Depression } \\
\text { Quality of life }\end{array}$ & $\begin{array}{l}\text { BDI } \\
\text { PDQL } \\
\text { STAI }\end{array}$ & $\begin{array}{l}\text { Significant improvements for depression, } \\
\text { anxiety, and QoL for the psychotherapy } \\
\text { group at post-intervention }\end{array}$ \\
\hline
\end{tabular}




\begin{tabular}{|c|c|c|c|c|c|c|c|}
\hline \multirow[t]{6}{*}{$\begin{array}{l}\text { Flores Alves } \\
\text { Dos Santos } \\
\text { et al., } 2017\end{array}$} & \multirow[t]{6}{*}{$\begin{array}{l}\text { Psychoeducati } \\
\text { on }\end{array}$} & \multirow[t]{6}{*}{$\mathrm{RCT}$} & $\begin{array}{l}\mathrm{I}: 7 \\
\mathrm{C}: 10\end{array}$ & \multirow[t]{6}{*}{$\begin{array}{l}\text { Group } \\
\text { psychoeducation } \\
\text { programme }\end{array}$} & $\begin{array}{l}\text { Anxiety } \\
\text { Coping }\end{array}$ & $\begin{array}{l}\text { CHIP } \\
\text { MADRS }\end{array}$ & \multirow{6}{*}{$\begin{array}{l}\text { Significantly greater improvements in } \\
\text { anxiety, depression and instrumental } \\
\text { coping for the treatment group at } 1 \text { year } \\
\text { No significant differences between } \\
\text { groups for quality of life }\end{array}$} \\
\hline & & & & & Depression & PDQ-39 & \\
\hline & & & & & Quality of life & SAS & \\
\hline & & & & & & STAI & \\
\hline & & & & & & WCC & \\
\hline & & & & & & WHOQOL & \\
\hline \multirow{4}{*}{$\begin{array}{l}\text { Guo et al., } \\
2009\end{array}$} & \multirow{4}{*}{$\begin{array}{l}\text { Psychoeducati } \\
\text { on }\end{array}$} & \multirow[t]{4}{*}{$\mathrm{RCT}$} & I: 23 & \multirow{4}{*}{$\begin{array}{l}\text { Educational } \\
\text { programme }\end{array}$} & Depression & PDQ-39 & Significant improvement in quality of life \\
\hline & & & C: 21 & & Quality of Life & PMS & No significant differences in depression \\
\hline & & & & & & SDS & \\
\hline & & & & & & SEADL & \\
\hline \multirow{3}{*}{$\begin{array}{l}\text { Macht et } \\
\text { al., } 2007\end{array}$} & \multirow{3}{*}{$\begin{array}{l}\text { Psychoeducati } \\
\text { on }\end{array}$} & \multirow{3}{*}{$\begin{array}{l}\text { Uncontrolled } \\
\text { pretest- } \\
\text { posttest }\end{array}$} & \multirow[t]{3}{*}{151} & \multirow{3}{*}{$\begin{array}{l}\text { Patient education } \\
\text { programme }\end{array}$} & Depression & BELA-P-k & \multirow{2}{*}{$\begin{array}{l}\text { Significant improvements for } \\
\text { psychosocial issues }\end{array}$} \\
\hline & & & & & \multirow[t]{2}{*}{ Quality of life } & PDQ-39 & \\
\hline & & & & & & SDS & $\begin{array}{l}\text { No significant improvements in } \\
\text { depression or quality of life }\end{array}$ \\
\hline \multirow[t]{2}{*}{$\begin{array}{l}\text { Soundy et } \\
\text { al., } 2019\end{array}$} & \multirow[t]{2}{*}{$\begin{array}{l}\text { Psychoeducati } \\
\text { on }\end{array}$} & \multirow[t]{2}{*}{$\begin{array}{l}\text { Qualitative } \\
\text { evaluation }\end{array}$} & \multirow[t]{2}{*}{18} & \multirow{2}{*}{$\begin{array}{l}\text { Peer-led } \\
\text { educational } \\
\text { intervention for } \\
\text { newly diagnosed } \\
\text { people with PD }\end{array}$} & \multirow[t]{2}{*}{ N/A } & \multirow[t]{2}{*}{ N/A } & $\begin{array}{l}\text { Program found as worth-while to } \\
\text { improve exercise behaviour and coping } \\
\text { mechanisms }\end{array}$ \\
\hline & & & & & & & $\begin{array}{l}\text { Proposed mechanisms of impact included } \\
\text { perceived control, social control, hope } \\
\text { and action, and individual mindset }\end{array}$ \\
\hline
\end{tabular}

Note. AARP = Abbreviated Treatment Acceptability Rating Profile; ACQ = Anxiety Control Questionnaire; ACT = Acceptance and Commitment Therapy; ADIS-5 = Anxiety Disorders Interview Schedule; ADL = Activities of Daily Living; AES = Apathy evaluation scale; AES-S = Apathy Evaluation Scale-Self; AIFQ = Adaptive Inferential Feedback Questionnaire; AS = Apathy Scale; ATQ-R = Automatic Thoughts Questionnaire-Revised; BA = Behavioural Activation; BAI = Beck Anxiety Inventory; $\mathbf{B A I}=$ Beck Anxiety Inventory; BBQ = Brunnsviken Brief Quality of life scale; BDI = Beck Depression Inventory; BELA-P-k = Burden Questionnaire for Patients with Parkinson's disease; BPRS = Brief Psychiatric Rating Scale; BRS = Behavioral Relaxation Scale; 
BRT $=$ Behavioural Relaxation Training; $\mathbf{C}=$ control $\mathbf{C B T}=$ Cognitive Behavioural Therapy; $\mathbf{C A S}=$ Clinical Anxiety Scale $\mathbf{C B T i}=\mathbf{C B T}$ for Insomnia; $\mathbf{C C L}=\mathrm{Cognitions}$ Checklist $\mathbf{C G I}=$ Clinical Global Impressions; CHIP = Coping Health Injuries and Problems; CORE-10 = Clinical Outcomes Routine Evaluation Scale, 10-item version; CSD-E = Expanded Consensus Sleep Diary for evening; DAS = Dysfunctional Attitude Scale; DASS = Depression, Anxiety and Stress Scale; DBAS-16 = Dysfunctional Beliefs and Attitudes about Sleep; EMDR = Eye Movement Desensitization and Reprocessing; EQ-5D = EuroQol-5 Dimension; ESS = Epworth Sleepiness Scale: FFMQ = Five Facet Mindfulness Questionnaire; FKK = Questionnaire for Disease-Related Communication; FMI = Freiburg Mindfulness Inventory; GAD-7 = Generalized Anxiety Disorder-7; GAI = Geriatric Anxiety Inventory; GDS = Geriatric Depression Scale; GHQ-28 = General Health Questionnaire; GSI = Global Severity Index; GRID-HAMD = GRID-Hamilton Depression Rating Scale; HADS = Hospital Anxiety and Depression Scale; HAM-A = Hamilton Anxiety Scale; HAM-D = Hamilton Depression Rating Scale; HWS = Holistic Well-being Scale; I = intervention; IQ = Inference Questionnaire; ISI = Insomnia Severity Index; IUS = Intolerance of Uncertainty Scale; IUS = Intolerance of Uncertainty Scale; LARS = Lille Apathy Rating Scale; LSAS = Liebowitz Social Anxiety Scale; MAAS = Mindful Attention Awareness Scale; MADRS = Montgomery-Asberg Depression Rating Scale; MBCT = Mindfulness Based Cognitive Therapy; MBSR = Mindfulness Based Stress Reduction; MCQ-30 = Metacognitions Questionnaire; MCS = Mental Health Composite Score; MHLC-B = Form B of the Multidimensional Health Locus of Control; MOS = Medical Outcome Study; N/A = Not Applicable; NEADL = Nottingham Extended Activities of Daily Living index; NPI = Neuropsychiatric inventory; OASIS= Overall Anxiety Severity and Impairment Scale; ODSIS= Overall depression severity and impairment scale; OQ-45 = Outcome Questionnaire; PAS = Parkinson's anxiety scale; PD = Parkinson's disease; PDQ = Parkinson's Disease Questionnaire; PDQL = Parkinson's Disease Quality of Life Questionnaire; PDSI = Parkinson's disease summary index score; PDSS = Parkinson's Disease Sleep Scale; PFS = Parkinson Fatigue Scale; PHQ-9 = Patient Health Questionnaire; PIRS20 = Pittsburgh Insomnia Rating Scale; PMS = Global patient's mood status; PSAS = PreSleep Arousal Scale; PSQI = Pittsburgh Sleep Quality Index; PSS = Perceived Stress Scale; PSWQ = Penn State Worry Questionnaire; RCT = Randomised Controlled Trial; SAS = Social adjustment scale; $\mathbf{S C I}=$ Sleep Condition Indicator; SCID = Structured Clinical Interview for DSM-IV; SCL-90$\mathbf{R}=$ Symptom Checklist-90 items-Revised; SDS = Self-Rating Depression Scale; SEADL = Schwab and England Activities of Daily Living; SES = Self-efficacy for sleep scale; SF-36 = Short Form Health Survey; SFQ = Social Feedback Questionnaire; SHI = Sleep Hygiene Index; SIGH-A = Structured Interview Guide for the Hamilton Anxiety Scale; SIGH-D = Structured Interview Guide for the Hamilton Depression Scale; SOGS = South Oaks Gambling Screen; SPAI = Social Phobia and Anxiety Inventory; SPEFI = Social Phobia Endstate Functioning Index; SQ = Kellner's Symptom Questionnaire; SRBQ-20 = Sleep-related behaviors questionnaire 20; SSPS = Self-Statements during Public Speaking Scale; STAI = State-Trait Anxiety Inventory; STAI-S $=$ State Anxiety Subscale of the STAI; STAI-T = Trait Subscale of the STAI; StAS = Starkstein Apathy Scale; SUD = Subjective Unit of Discomfort; UPDRS = Unified Parkinson's Disease Rating Scale; WCC = Ways of Coping Checklist; WHOQOL = World Health Organisation Quality of Life-Brief. 
Figure 1. PRISMA diagram for selection of studies.



